Wilfrid Laurier University

Scholars Commons @ Laurier

$1-2006$

\title{
The Biology of Canadian Weeds. 133. Cuscuta campestris \\ Yuncker, $C$. gronovii Willd. ex Schult., C. umbrosa Beyr. ex Hook., C. epithymum (L.) L. and C. epilinum Weihe
}

Mihai Costea

Wilfrid Laurier University, mcostea@wlu.ca

François J. Tardif

University of Guelph

Follow this and additional works at: https://scholars.wlu.ca/biol_faculty

Part of the Biology Commons

\section{Recommended Citation}

Costea, Mihai and Tardif, François J., "The Biology of Canadian Weeds. 133. Cuscuta campestris Yuncker, C. gronovii Willd. ex Schult., C. umbrosa Beyr. ex Hook., C. epithymum (L.) L. and C. epilinum Weihe" (2006). Biology Faculty Publications. 77.

https://scholars.wlu.ca/biol_faculty/77

This Article is brought to you for free and open access by the Biology at Scholars Commons @ Laurier. It has been accepted for inclusion in Biology Faculty Publications by an authorized administrator of Scholars Commons @ Laurier. For more information, please contact scholarscommons@wlu.ca. 


\title{
The biology of Canadian weeds. 133. Cuscuta campestris Yuncker, C. gronovii Willd. ex Schult., C. umbrosa Beyr. ex Hook., C. epithymum (L.) L. and C. epilinum Weihe.
}

\author{
Mihai Costea ${ }^{1}$ and François J. Tardif ${ }^{2}$ \\ Department of Plant Agriculture, Crop Science Building, University of Guelph, Guelph, \\ Ontario, Canada N1G2W1 (e-mail: mcostea@wlu.ca and2ftardif@uoguelph.ca). \\ Received 3 May 2004, accepted 21 January 2005.
}

\begin{abstract}
Costea, M. and Tardif, F. J. 2006. The biology of Canadian weeds. 133. Cuscuta campestris Yuncker, C. gronovii Willd. ex Schult., C. umbrosa Beyr. ex Hook., C. epithymum (L.) L. and C. epilinum Weihe. Can. J. Plant Sci. 86: 293-316. Cuscuta spp. (dodders) are rootless, holoparasitic herbs with filiform stems attached to the host by numerous haustoria. In Canada, Cuscuta gronovii is the most common native species of the genus followed by Cuscuta campestris and C. umbrosa. Cuscuta epithymum and C. epilinum, both introduced species in Canada, occur occasionally. Infestation by Cuscuta spp. can result in serious yield losses and dodders are listed as noxious weeds in British Columbia, Ontario and Québec, and as restricted weeds in Alberta. These plants have evolved special adaptations to ensure their success: germination occurs late in the season when potential hosts are already established; seedlings selectively forage in plant communities and they may survive relatively long periods during the autotrophic stage. Invasion occurs via extremely elaborate mechanisms designed to match the biological processes of their host and bypass defense mechanisms. The principal means of dispersal of Cuscuta weeds world-wide (including Canada) has been through contaminated seeds of previously infested forage legumes. In other areas (e.g., Israel), C. campestris has developed resistance to ALS inhibitors (chlorsulfuron, and sulfometuron-methyl) and AABI herbicides. Complete descriptions and illustrations are provided for discussed species.
\end{abstract}

Key words: Cuscuta campestris, C. gronovii, C. umbrosa, C. epithymum, C. epilinum, parasitism, growth, development, physiology, reproduction, control, diseases

Costea, M. et Tardif, F. J. 2006. La biologie des mauvaises herbes au Canada. 133. Cuscuta campestris Yuncker, C. gronovii Willd. ex Schult., C. umbrosa Beyr. ex Hook., C. epithymum (L.) L. et C. epilinum Weihe. Can. J. Plant Sci. 86: 293-316. Les plantes du genre Cuscuta (cuscutes) sont des herbacées holoparasites sans racines dont la tige filiforme se fixe à l'hôte par de nombreux haustoria. Au Canada, Cuscuta gronovii est l'espèce indigène la plus courante, suivie de Cuscuta campestris et de C. umbrosa. On rencontre à l'occasion Cuscuta epithymum et C. epilinum, deux espèces introduites. Les infestations par Cuscuta sp. peuvent entraîner d'importantes pertes de rendement et les cuscutes figurent parmi les plantes nuisibles en ColombieBritannique, en Ontario et au Québec, ainsi que parmi les adventices réglementées en Alberta. La plante s'est adaptée pour mieux prospérer : germination tardive quand les hôtes potentiels se sont déjà établis; plantules exploitant sélectivement les communautés végétales et pouvant survivre relativement longtemps pendant le stade autotrophe. L'invasion survient grâce à des moyens extrêmement élaborés, adaptés aux processus biologiques de l'hôte et qui court-circuitent ses mécanismes de défense. Le principal moyen de dispersion des cuscutes, partout dans le monde (y compris au Canada), est la contamination des semences de légumineuses fourragères antérieurement infestées. Dans certains pays (en Israël notamment), $C$. campestris a développé une résistance aux herbicides inhibant l'ALS (chlorsulfuron et méthyle de sulfométuron) et aux désherbants AABI. Suit une description complète et des illustrations des différentes espèces.

Mots clés: Cuscuta campestris, C. gronovii, C. umbrosa, C. epithymum, C. epilinum, parasitisme, croissance, développement, physiologie, reproduction, lutte, maladies

\section{Names}

I. Cuscuta campestris Yuncker-field dodder (Darbyshire 2003), cuscute des champs (Darbyshire 2003). Bayer code: CVCCA.

II. C. gronovii Willd. ex Schult.—swamp dodder (Darbyshire 2003), cuscute de Gronovius (Darbyshire 2003). Bayer code: CVCGR.

III. Cuscuta umbrosa Beyr. ex Hook. (C. megalocarpa Rydberg; C. curta (Engelm.) Rydberg) - large-fruited dodder (Darbyshire 2003), cuscute à gros fruits (Darbyshire 2003). Bayer code: CVCUB.
IV. C. epithymum (L.)L.—clover dodder (Darbyshire 2003), cuscute du thym (Darbyshire 2003). Bayer code: CVCEY. V. C. epilinum Weihe.-flax dodder (Darbyshire 2003), cuscute du lin (Darbyshire 2003). Bayer code: CVCEP.

The etymology of the generic name is Aramaic and/or Hebrew. The triradical root of the verb K-S-Y (Kaph, Shin, Yodh) means "to cover". Based on this root, a verbal noun that signifies "cover," "clothing" or "garment" is constructed in both languages: K-S-W-T (in Hebrew) and K-S-W-TA (Kaph, Shin, Waw, Tav, Aleph) in Aramaic (Costea and Tardif 2004). "Campestris" in Latin means "that grows in 
the field". The specific epithet "gronovii" commemorates the Dutch botanist Gronovius, who apparently was the first who referred to the species; "epi" from "epithymum" and "epilinum" means "on" or "over" (Thymus and Linum, respectively). Dawson et al. (1994) suggested that the vernacular name, "dodder," may come from an old German word, "dotter," used to describe the yolk of an egg. Other vernacular names generally used in North America for Cuscuta spp. are "love vine," "tangle gut," "strangle vine," "devil's gut," and "witches shoelaces" (Yuncker 1965).

Convolvulaceae, Convolvulacées. Major synoptic works of angiosperms have treated dodders within a separate family of a single genus (Cuscutaceae) (e.g., Takhtajan 1997; Cronquist 1988). Although preliminary results from mitochondrial gene and intron sequences have suggested a sister relationship with Convolvulaceae (McNeal and DePamphilis 2000), more recent phylogenetic studies indicate that Cuscuta belongs within Convolvulaceae (Stefanovic et al. 2002; Stefanovic and Olmstead 2004).

\section{Description and Account of Variation}

(a) Description (Yuncker 1921, 1932, 1965) — All Cuscuta spp. are rootless parasitic herbs, annual or sometimes perennial. Stems are filiform, yellow, orange, or reddish, glabrous, trailing or dextrorsely twining and attached to the host by numerous small haustoria. Leaves are reduced to alternate, minute scales. Inflorescences are cymose. Flowers are bisexual, regular, sessile or short-pedicellate, mostly 4or 5-merous, thickened-fleshy to thin-membranous; calyx is fused at the base; corolla is gamopetalous, campanulate to tubular, with small, fringed or fimbriate-margined scale-like appendages (infrastaminal scales) adnate to the corolla tube and alternating with the corolla lobes. Stamens are (3-)5, alternating with the corolla lobes; styles 2, terminal with stigmas capitate or linear. Fruit is a capsule, indehiscent, irregularly dehiscent, or circumscissile by a more or less regular line near the base. There are 1-4 seeds per capsule.

I. Cuscuta campestris (Figs. 1A, 2C)—Stems are slender to medium (0.40-0.60 $\mathrm{mm}$ thick), yellow to orange. Inflorescences are dense, corymbiform or glomerulate of (3-)6-25 (-30) subsessile to short pedicellate flowers (pedicels $0.3-2.5 \mathrm{~mm}$ long). Flowers are (4-)5-merous, 2.1-4.6(-5) mm long, white, membranous, with pellucid, gland-like laticiferous cells evident in the calyx and less obvious in the corolla, ovary and capsule. Calyx is cupulate, ca. as long as the corolla tube, divided $2 / 5-3 / 5$ the length, calyx lobes are ovate-triangular, obtuse, basally overlapping. Corolla tube is campanulate, ca. 1.5-1.9 mm long, corolla lobes are triangular-lanceolate, acute, inflexed at the tip, ca. as long as the tube, spreading to reflexed. Stamens are exserted; anthers are broadly elliptic, $0.3-0.5 \mathrm{~mm}$ long; filaments are 0.4-0.7 mm long. Infrastaminal scales are oblong-ovate, fringed, reaching the filament bases and often exerted. Styles are filiform, $0.8-1.6 \mathrm{~mm}$, ca. as long as the ovary; stigmas are capitate, globose. Capsules are indehiscent or irregularly dehiscent, depressed-globose to depressed, 1.3-3 × 1.9-3.5 $\mathrm{mm}$, with a large and conspicuous interstylar aperture, with the withered corolla surrounding the lower part. Seeds are 4 per capsule. Chromosome numbers. No chromosome counts are available from Canada. A chromosome number of $n=28$ chromosomes was reported from the United States (Fogelberg 1938); $2 n=56$ was reported from New Mexico (Ward 1984), Israel (as “C. pentagona”, Pazy and Plitmann 1995) and Iran (Aryavand 1987).

II. Cuscuta gronovii (Fig. 1B, 2A, D)-Stems are medium to coarse $(0.40-0.80 \mathrm{~mm}$ thick), yellow to orange. Inflorescence is loose or dense, paniculiform of 7-40 subsessile to pedicellate flowers (pedicels 1-4.5 mm long), sometimes originating endogenously. Flowers are (4-)5merous, 2-4(-4.7) $\mathrm{mm}$, white, membranous, with a few to many pellucid, gland-like laticiferous cells evident in the calyx, corolla, ovary and capsule. Calyx is cupulate to shortcampanulate, commonly reaching to ca. the middle of the corolla tube, divided $1 / 2-2 / 3$ the calyx length; calyx lobes are ovate to suborbicular or oblong, obtuse, basally overlapping. Corolla tube is campanulate, (1-)1.5-2.5(-3) $\mathrm{mm}$ long; corolla lobes are mostly ovate, rounded-obtuse, $1 / 2-1 / 3$ the length of the corolla tube, spreading. Stamens are exserted; anthers are ovate to oblong, 0.3-0.6 $\mathrm{mm}$ long; filaments are $0.4-0.7(-1) \mathrm{mm}$ long. Infrastaminal scales are oblong, deeply fringed distally, reaching the filament bases. Styles are slender or occasionally slightly subulate, (0.6-)1.2-2.2 mm long, shorter than- to equaling the ovary; stigmas are capitate, globose. Capsules are indehiscent to irregularly dehiscent, ovoid to globose-conic or subobpyriform, 2.5-4.5 $(-5.2) \times 2-4(-5) \mathrm{mm}$, surrounded or capped by the withered corolla. Seeds are 2-4 per capsule. Chromosome numbers-available from Madison, Wisconsin, $n=30$ (Fogelberg 1938).

III. Cuscuta umbrosa (Fig. 1C)—Stems are medium to coarse (0.40-0.80 mm thick), yellow to orange. Inflorescences are dense, paniculiform of 5-30 subsessile to pedicellate flowers (pedicels 1-7 mm long), becoming globular through the growth and crowding of the capsules. Flowers are (4-)5-merous, 2-3.5(-4.4) mm long, membranous, white, with a few to many pellucid, gland-like laticiferous cells evident in the calyx, corolla, ovary and capsule. Calyx is campanulate reaching to ca. the middle of the corolla tube, divided 1/2-2/3 the calyx length; lobes are ovate, rounded or obtuse, basally overlapping. Corolla tube is campanulate, 1.7-2.3(-2.7) $\mathrm{mm}$ long; corolla lobes are mostly ovate to broadly triangular ovate, rounded-obtuse, 1/3-1/4 the length of the tube corolla tube, spreading or reflexed. Stamens are exserted; anthers are ovate to oblong, 0.3-0.6 mm long; filaments are $0.4-0.7 \mathrm{~mm}$ long. Infrastaminal scales are broadly oblong, and apically truncate to slightly bilobed, fringed, $1 / 2(-1 / 3)$ as long as the tube. Styles are slender, thickened at the base $0.3-0.7(-0.9)$ $\mathrm{mm}$ long, ca. 1/4 as long as the ovary; stigmas are capitate, globose. Capsules are indehiscent or irregularly dehiscent, subglobose, ovoid to globose-conic, 3.5-6.5(-7) × 3-5(-6) $\mathrm{mm}$, surrounded or capped by the withered corolla. Seeds are 3-4 per capsule. Chromosome numbers-not available.

IV. Cuscuta epithymum (Figs. 1D, 2E)—Stems are slender $(0.25-0.40 \mathrm{~mm}$ thick), yellow or often reddish or purplish. 
Inflorescences are compact, glomerulate of 7 to 25 sessile flowers. Flowers are 5-merous, 3-4(-5) mm long, fleshy, white-creamy and sometimes reddish-tinged, laticiferous cells are visible in corolla and the midveins of calyx lobes. Calyx is cupulate, $1 / 2-2 / 3$ as long as the corolla tube, divided $1 / 2-2 / 3$ the length; calyx lobes are ovate-triangular, acute, sometimes purplish, basally overlapping. Corolla tube is campanulate-cylindrical, 2-3 mm long; corolla lobes are triangular, acute, $3 / 4-1 / 2$ as long as the corolla tube, spreading. Stamens are exserted; anthers are ovate, $0.3-0.5$ $\mathrm{mm}$ long; filaments are $0.4-0.7 \mathrm{~mm}$ long. Infrastaminal scales are oblong-spathulate, distally fringed, ca. $4 / 5$ as long as the corolla tube. Styles are terete, stigma plus style 1.2-2.2 $\mathrm{mm}$ long, ca. two times longer than the ovary; stigmas are filiform-elongate, appearing as a continuation of the style. Capsules are circumscissile, globose, 1.6-2.2 $\times$ $1.6-2.3 \mathrm{~mm}$, capped by the withered corolla. Seeds are 4 per capsule. Chromosome numbers $-n=7 ; 2 n=14$ available only from Europe and Asia (Pazy and Plitmann 1995).

V. Cuscuta epilinum (Figs. 1E, 2F)-Stems are slender to medium (0.30-0.60 mm thick), yellow to orange. Inflorescences compact, glomerulate of 4 to 15 sessile flowers. Flowers are 5-merous, 3-4 mm long, membranous, white-creamy, without laticiferous cells. Calyx is cupulate, nearly as long as the corolla tube and enclosing it, divided ca. $1 / 2$ the length; calyx lobes are broadly ovate, bluntly acute, often mucronate, basally overlapping. Corolla tube is urceolate, $2.5-3 \mathrm{~mm}$ long; corolla lobes are ovate-triangular, obtuse to acute, $1 / 4-1 / 3(-1 / 2)$ as long as the corolla tube, erect. Stamens are included or barely exerted; anthers are ovate, $0.3-0.5 \mathrm{~mm}$ long; filaments are $0.2-0.4 \mathrm{~mm}$ long. Infrastaminal scales are spatulate, truncate, entire or bifid, apically short-fimbriate, sometimes reduced to short wings, $3 / 4-4 / 5$ of the corolla tube. Styles are terete, stigma plus style $0.5-1.1 \mathrm{~mm}$ long, shorter than the ovary; stigmas are terete-elongate, appearing as a continuation of the style. Capsules are circumscissile depressed-globose, angular around the seeds, $2.8-3.5 \times 3-4.2 \mathrm{~mm}$, capped by the withered corolla. Seeds are 4 per capsule, usually connate in pairs. Chromosome numbers $-2 n=42$ recorded from Russia (Pazy and Plitmann 1995).

(b) Distinguishing features-Cuscuta spp. cannot be confused with any other plants. The genus Cassytha from Lauraceae (or sometimes Cassythaceae) superficially resembles Cuscuta, but it has not been reported from Canada. Identification of Cuscuta species requires the rehydration of flowers in boiled water for 10-30 min, if plants are dry, and their dissection and examination under a microscope. Identification keys for Cuscuta are available for species occurring throughout the world (Yuncker 1932), North America (Yuncker 1965), Canada (Scoggan 1979) and Ontario (Crins and Ford 1988).

\section{(c) Intraspecific variation}

I. Cuscuta campestris - This species is part of a controversially taxonomic complex of selfing annuals. Yuncker (1932, 1965) accepted C. campestris as a separate species, distinct from C. pentagona Engelm. Engelmann (1859) previously treated these two species as varieties: $C$. pentagona var. pentagona and C. pentagona var. calycina Engelm., respectively. More recently, the two related taxa have been considered conspecific, and were given no infraspecific rank (e.g., Beliz 1986; Kartesz 1998). This creates problems because although in most of the cases the two taxa are distinguishable, many recent references to " $C$. pentagona" actually apply to $C$. campestris, which is more common and more aggressive as a weed. Cuscuta campestris is accepted as a species in the forthcoming treatment of the genus in Flora of North America (Costea et al. unpublished). The two taxa can be recognized as follows:

1. Flowers 1.4-2.1(-2.5) mm long; calyx angled, lobes broadly-ovate rhombic, forming prominent angles at sinuses; corolla tube $0.7-1.2 \mathrm{~mm}$ long; anthers $0.2-0.30 \mathrm{~mm}$ long; capsules 1.9-2.4 × 1.6-2.5 mm .......Cuscuta pentagona 1. Flowers 2.1-4.6(-5) mm long; calyx not angled (rounded), lobes ovate-triangular, not forming prominent angles at sinuses; corolla tube 1.1-2.5 mm long; anthers $0.4-0.7 \mathrm{~mm}$ long; capsules 1.3-3 × 1.9-3.5 mm ..Cuscuta campestris Cuscuta campestris is also related to C. glabrior (Engelm.) Yuncker, C. runyonii Yuncker, C. harperi Small and $C$. plattensis Nelson, taxa that do not grow in Canada (Yuncker 1965).

II. Cuscuta gronovii is morphologically variable and several varieties have been described (e.g., Engelmann 1859). Cuscuta gronovii var. calyptrata Engelm. has corollas that cape the capsules. Variety latiflora Engelm. has a corolla tube that is short and campanulate, equaling the calyx lobes.

III. Cuscuta umbrosa-Described originally as a variety, $C$. gronovii var. curta Engelm., has been accepted as a distinct species in the forthcoming treatment of the genus for Flora of North America (Costea et al. unpublished). At the other extreme, Crins and Ford (1988) did not recognize this taxon at any rank, considering it conspecific with $C$. gronovii. This taxon is fairly homogenous.

IV. Cuscuta epithymum exhibits considerable variation in Europe, where two subspecies and several varieties have been described (Feinbrun 1970). The North American material belongs to C. epithymum subsp. epithymum.

\section{Cuscuta epilinum is fairly homogenous.}

(d) Illustrations - Line drawings of flowers, capsules, opened corollas and calyces for the five species are presented in Fig.1. Additional images can be found in Yuncker (1932). Scanning electron microscope pictures of the seeds, as well as of a flower and pollen of $C$. gronovii can be seen in Fig. 2.

\section{Economic Importance}

(a) Detrimental - Cuscuta campestris is a weed of at least 25 crops in 55 countries, while C. epithymum is a weed of 25 crops in 13 countries (Holm et al. 1997). Crops infested by $C$. campestris include: alfalfa (Medicago sativa $\mathrm{L}$.), 

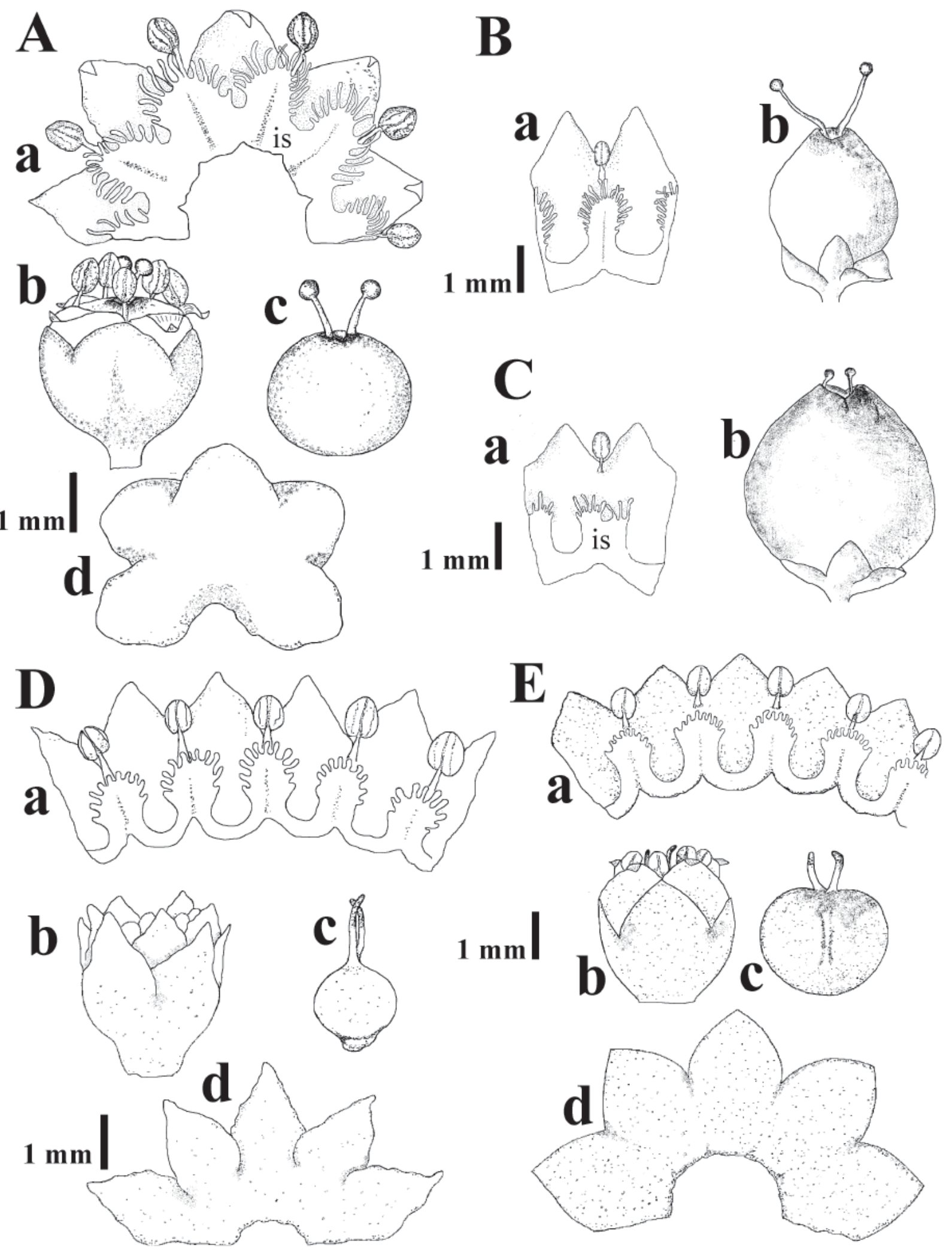

Fig. 1. A. Cuscuta campestris: a. opened corolla, b. flower, c. capsule, d. opened calyx., B. C. gronovii: a. opened corolla, b. capsule. C. C. umbrosa: a. opened corolla, b. capsule. D. C. epiphytum: a. opened corolla, b. flower, c. capsule, d. opened calyx. E. C. epilinum: a. opened corolla, b. flower, c. capsule, d. opened calyx. is = infrastaminal scales. 

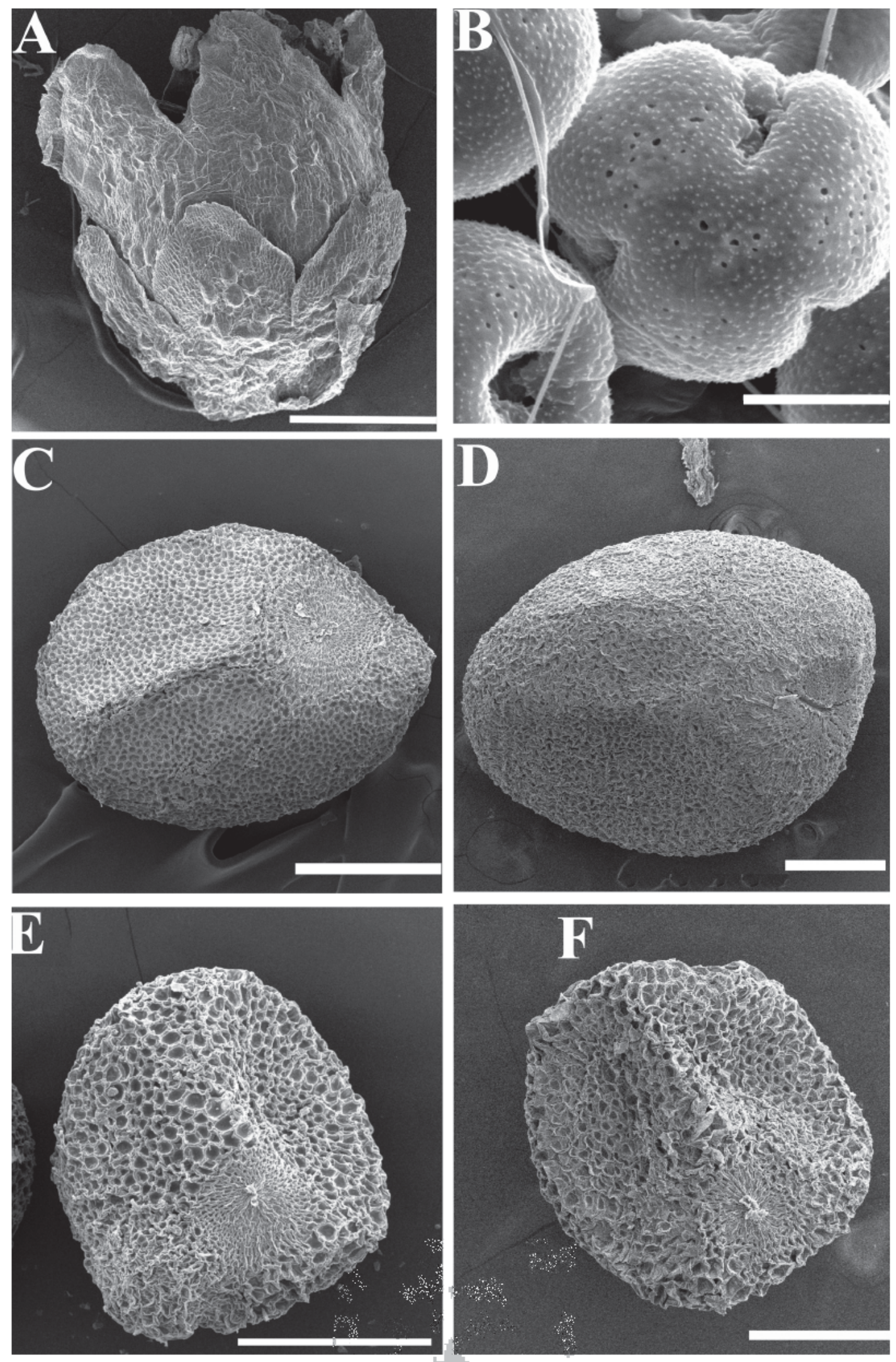

Fig. 2. A. Flower of Cuscuta gronovii (scale bar $=1 \mathrm{mrt}$. Ro Polleng of gronovii (scale bar $=7.5 \mu \mathrm{m}$ ), C-F. Seeds of: C. C. campestris, D. C. gronovii, E. C. epiphytum, F. C. epilinum. Scale bar $=0.5 \mathrm{~mm}$ 
clover (Trifolium spp.), fababean (Vicia faba L.), beets (Beta vulgaris L.), carrots (Daucus carota L.), and to lesser extent asparagus (Asparagus officinalis L.), chickpeas (Cicer arietinum L.), grapevine (Vitis vinifera L.), honeydew melon (Cucumis melo L.), onions (Allium cepa L.), potatoes (Solanum tuberosum L.), tomatoes (Lycopersicon esculentum Mill.), eggplants (Solanum melongena L.) and some ornamental plants (e.g., Tanacetum spp.) (Cooke and Black 1987; Parker and Riches 1993; Dawson et al. 1994; Kroschel 2001). Cuscuta epithymum is an economically important weed mainly in clover (Kroschel 2001); C. epilinum in flax (Linum usitatissimum L.), and C. gronovii in cranberry (Vaccinium macrocarpon Ait.), grapevine and Citrus spp. (Parker and Riches 1993; Kroschel 2001).

Infestation by Cuscuta can result in serious yield losses. Dawson (1989) reported a 57\% reduction in forage yield of alfalfa in Prosser, Washington following an artificial infestation with $C$. campestris over a 2 -yr period. In Idaho, potatoes planted after an infested alfalfa crop were completely destroyed (Dawson et al. 1994). Cuscuta gronovii infesting cranberry fields in Wisconsin reduced the yield by at least $50 \%$ (Bewick et al. 1988b). In Kirgizia, C. campestris infestation caused a reduction in sugarbeet yield and sugar content by $3.54 \mathrm{t} \mathrm{ha}^{-1}$ and 1.5-1.9\%, respectively (Belyaeva et al. 1978). In Yugoslavia, over $80 \%$ of the alfalfa and red clover (Trifolium pratense L.) fields were infested with C. campestris, and $20 \%$ of these crops had to be abandoned (Stojanovic and Mijatovic 1973). Sugarbeet plants infested with C. campestris had the root weight and sugar content decreased by $23-41 \%$ and $1.3-2.6 \%$, respectively (Stojsin et al. 1991).

Cuscuta spp. seeds are important contaminants, especially of small-seeded forage legumes (Knepper et al. 1990; Dawson et al. 1994). Seed contamination represents the main way the parasite spreads, and infested seed lots are denied entry at the border of most countries including Canada and United States. Cleaning of infested seed lots requires significant additional costs (Dawson et al. 1994) and reduces the quality of cleaned seeds (Caji and Stjepanovi 1995).

Although Cuscuta spp. are usually not mentioned among toxic plants in North America (e.g., Evers and Link 1972; Stephens 1980; Lampe and McCann 1985; Mulligan and Munro 1990), dodders have been suspected to be toxic to humans (Perkins and Payne 1978) and livestock (Kingsbury 1964). Movsesyan and Azaryan (1974) reported that $C$. campestris can be poisonous to animals if it exceeds $5 \%$ of the total roughage. Ingestion of this species by rabbits, horses and cattle caused a toxicosis characterized by anorexia, increased peristalsis followed by atonia, diarrhea, vomiting, increased pulse and respiration rates (Movsesyan and Azaryan 1974).

(b) Beneficial - Cuscuta spp. have long been used in folk medicine (Blatter et al. 1988; Bork et al. 1996; Srivastava 2002) and they have been extensively investigated as medicinal plants. Cuscuta spp. is an ingredient in a Chinese herbal mixture (Zuo-gui-wan), which was reported to restore ovarian function in women with premature ovarian failure (POF) and secondary amenorrhea (Chao et al. 2003).
A different herbal mixture containing Cuscuta chinensis Lam. was suggested as a new approach in the treatment and prevention of postmenopausal osteoporosis (Xu et al. 2003). Flavonoids extracted from the seeds of $C$. chinensis stimulated the reproductive system and reproductive endocrine function in male rats (Qin et al. 2003). Water extract of $C$. chinensis reduced the incidence of skin carcinoma in mice, and had anti-inflammatory activity (Nisa et al. 1985, 1986). The anti-inflammatory effect was confirmed in $C$. campestris (Agha et al. 1996) and C. tinctoria Mart. ex Engelm. (Bork et al. 1996). A commercial herbal mixture, Equiguard $^{\mathrm{TM}}$, which contains $C$. chinensis was reported to prevent or correct dysfunctional mechanisms that accompany prostate carcinogenesis by modulating prostate growth and gene expression (Hsieh et al. 2002). Cuscuta reflexa Roxb. contains $\alpha$-glucosidase inhibitory constituents and is a potential therapeutic source against diabetes (Anis et al. 2002). Cuscuta pentagona can be used as a dye for wool (Dawson et al. 1994). Some species, e.g., C. reflexa, have antifungal (Mohammad. et al. 1984) and insecticidal effects (Chavan et al. 1982). In India, Cuscuta santapaui Banerji \& Das has been successfully tested as a biocontrol agent against Lantana camara L. (Pundir 1985).

(c) Legislation - In Canada, Cuscuta spp. are listed as noxious weeds in British Columbia, Manitoba, Ontario and Québec, and as restricted weeds (destroyed when found) in Alberta (Invaders Database System 2004). In the United States, Cuscuta spp. are listed in the Federal Noxious Weed List and on the State lists of 20 states (Invaders Database System 2004). Seeds of Cuscuta spp. are prohibited by the Canada Weed Seeds Order (Anonymous 1986) and by the laws of all states in the United States (Dawson et al. 1994; Holm et al. 1997). Commercial seed/crop shipments found to contain Cuscuta seeds at the border of Canada and the United States are denied entry.

\section{Geographical Distribution}

I. Cuscuta campestris - This apparently native species occurs sporadically in British Columbia, Alberta, Saskatchewan, Ontario and Québec (Fig. 3 ). Cuscuta pentagona s.tr., often synonymized with $C$. campestris, was collected only on one occasion by Macoun at 1872 from Manitoba (collection in MTMG). Cuscuta campestris is perhaps the most widely distributed world-wide species of the genus. Although it originated in North America, the species is now semicosmopolitan being recorded from South America, Europe, Asia, Africa and Australia (Holm et al. 1997).

II. Cuscuta gronovii-As a native species, it is the most common dodder in Canada and occurs mostly in Ontario, Québec, New Brunswick and Nova Scotia (Fig. 4). Originally from North America, this species has also spread in Europe, especially along water courses (Parker and Riches 1993).

III. Cuscuta umbrosa-This native species grows in Eastern Alberta, Saskatchewan and Manitoba (Fig. 4). 


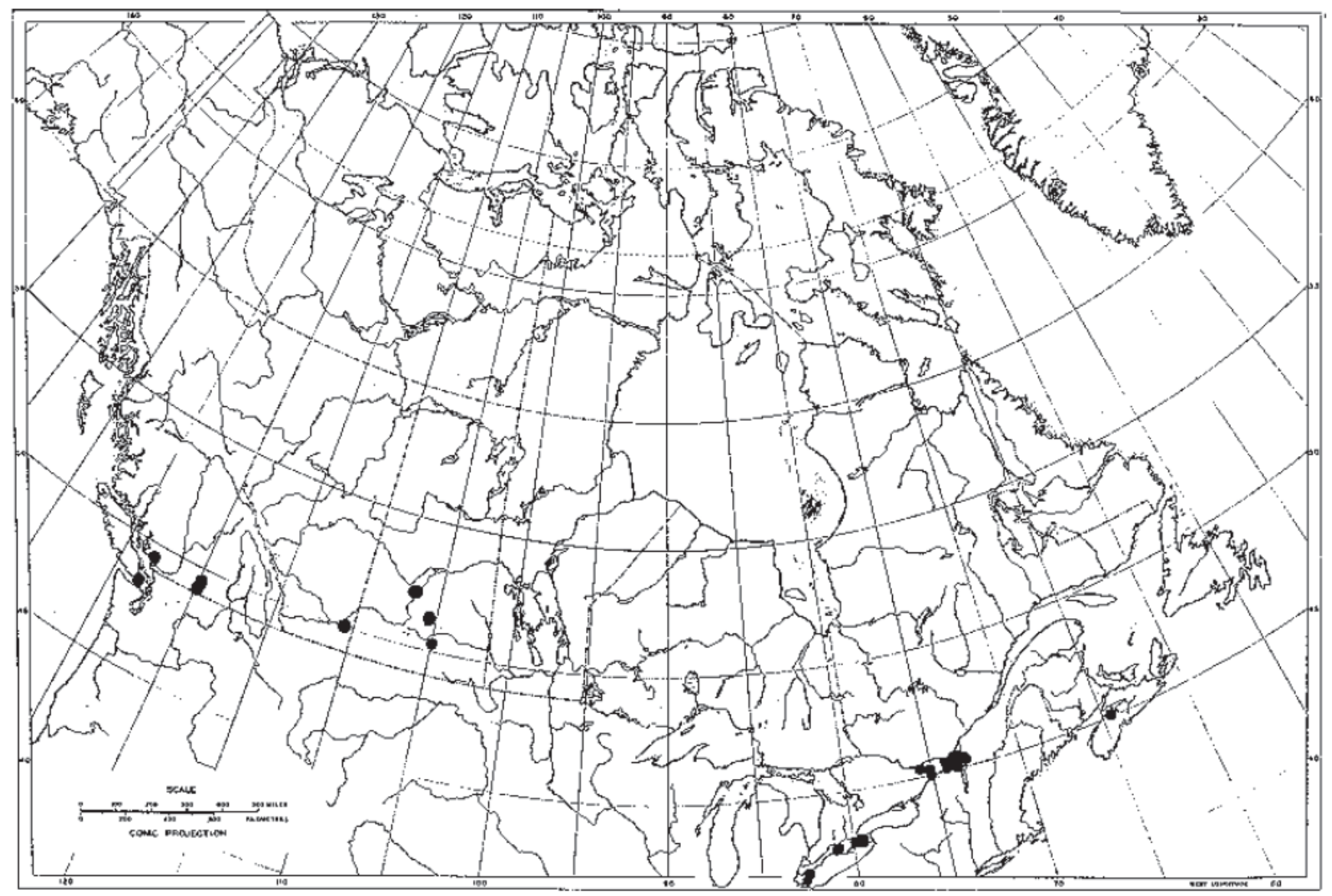

Fig. 3. Distribution of Cuscuta campestris in Canada. [ACAD, ALTA, DAO, HAM, MT, MTMG, NFLD, NSPM, NY, OAC, QFA, QUE, RBG, SASK, SFS, TUP, UBC, UNB, USAS, UWO, UWPG, WAT, WIN and WIS; herbarium abbreviations according to Holmgren et al. (1990)].

IV. C. epithymum-This species occurs sporadically in British Columbia, Ontario, Québec and New Brunswick (Fig. 5). This European and western Asian species has introduced to North America, eastern Asia (e.g., Japan), Africa, South America and Australia (Holm et al. 1997).

V. C. epilinum-This species originated from Europe and western Asia but may occur sporadically in North America and Africa (Parker and Riches 1993). In Canada, it has been found in Québec (Fig. 5) and there is a specimen collected by Pringle from "Lower Canada" at 1880 (deposited in MTMG).

\section{Habitat}

(a) Climatic requirements - The four species can be considered temperate to subtropical, with $C$. campestris exhibiting the widest climatic range. The preference towards a temperate climate is probably related to the cycle of dormancy undergone by the seeds in the soil (see Section 7). The ecological preferences for temperature and light are known only for the germination and seedling phases (see Section 7), and are virtually unknown for the parasitizing stage. Water is necessary for the imbibition of seeds during germination (see Section 7). Parker and Riches (1993) mentioned that $C$. campestris in Ethiopia grows poorly in humid seasons and Stojsin et al. (1991) reported that the attack of this species on sugarbeet was more intense in dry summers.

(b) Substratum - The influence of substratum during the autotrophic stage is poorly known (see Section 8c). If substratum has any direct effect during the parasitic stage, it is unknown. However, substratum influences Cuscuta spp. indirectly through the host.

(c) Communities in which the species occur - Cuscuta spp. occur in the communities of their hosts.

Gaertner (1950) reviewed the literature on host range of Cuscuta spp.: C. campestris, C. epithymum, and C. gronovii were reported to parasitize 116,147 , and 175 species, respectively. However, the number is certainly much higher. Interestingly, some species have a narrow host range (e.g., C. epilinum), while others are capable of parasitizing numerous species from various families. Even species with a wide host range may show a preference toward certain species, and exhibit a partial or total incompatibility with other species, or only with certain populations or cultivars of 


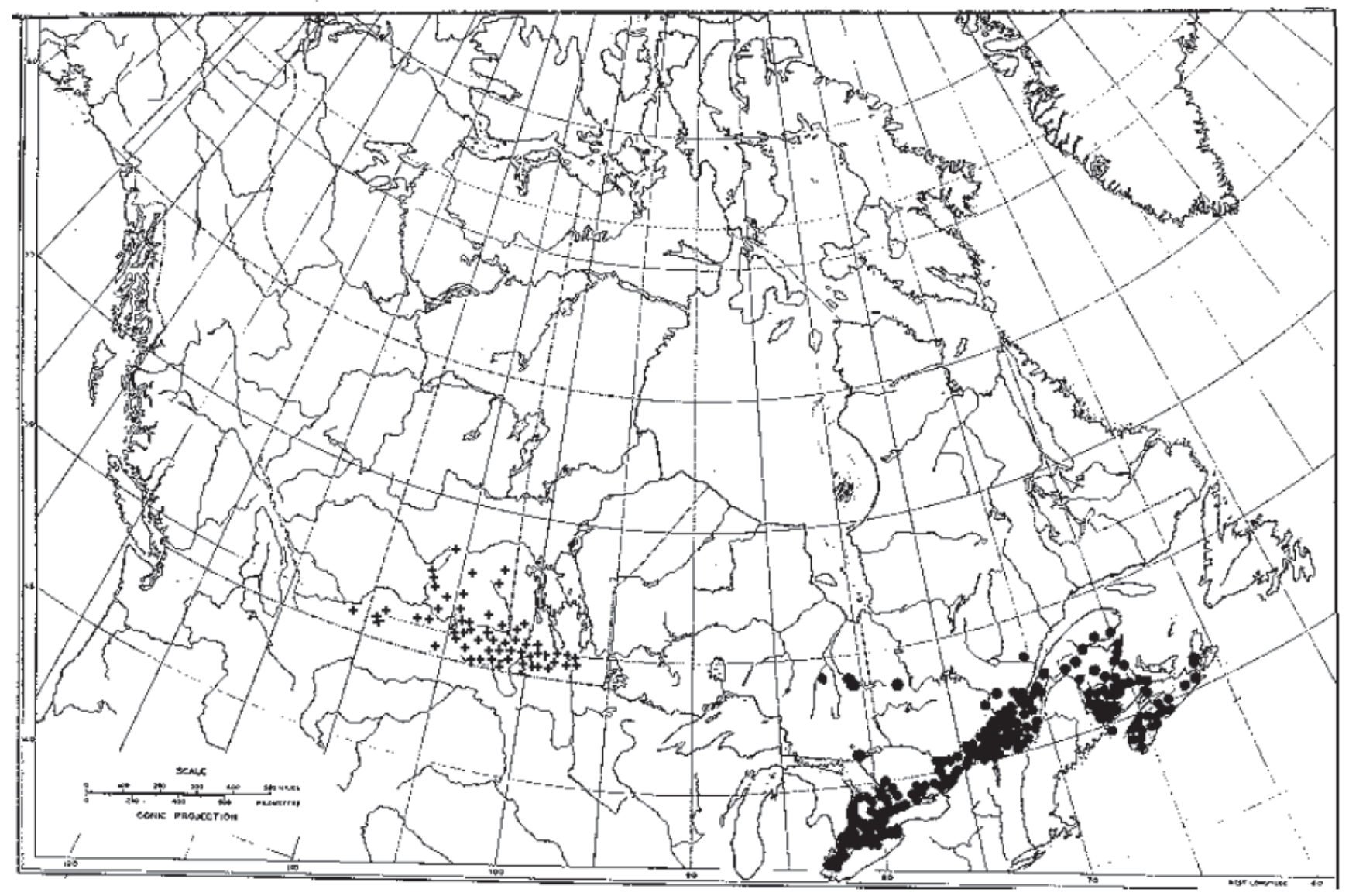

Fig. 4. Distribution of Cuscuta gronovii (dots) and C. umbrosa in Canada (crosses). [ACAD, ALTA, DAO, HAM, MT, MTMG, NFLD, NSPM, NY, OAC, QFA, QUE, RBG, SASK, SFS, TUP, UBC, UNB, USAS, UWO, UWPG, WAT, WIN and WIS; herbarium abbreviations according to Holmgren et al. (1990)].

these (see also Section 7a). Cuscuta campestris could not survive on Azolla caroliniana Willd., Equisetum arvense L., Elaeocharis rostellata Torr., Atriplex spp., Amaranthus retroflexus L., Portulaca oleracea L., Brassica nigra Koch., Glycine max (L. ) Merr., Vicia villosa Roth., Lycopersicon esculentum, Arctium lappa L. or Tanacetum vulgare L. (Gaertner 1950).

Parker and Riches (1993) distinguished primary and secondary hosts. Primary hosts are those plants on which Cuscuta spp. can establish from the seedling stage. Secondary hosts are those plants on which the seedling parasite cannot establish, but with which they can connect once the parasite has established itself on a primary host. For example, the primary host range of C. epilinum is limited to Linum spp., but once established on the latter, it can attach on other dicotyledonous species as well (e.g., Impatiens spp., Gaertner 1950). Plants from Poaceae and Cyperaceae are incompatible as primary hosts (Dawson et al. 1994), but Parker and Riches (1993) hypothesized that some monocot species may act as secondary hosts, at least for some Cuscuta spp. However, although Cuscuta spp. may twine around grasses, no haustorial connections were observed (Rath and Mohanty 1988; Dawson et al. 1994).

\section{History}

The history of Cuscuta parasitism during ancient and medieval times has been investigated by Costea and Tardif (2004). Several Cuscuta spp. (C. tinctoria L., C. americana L., C. odontolepis Engelm.) were used by the Aztecs to produce a yellow dye called "Zacatlaxcalli" (Sahagún 1950-1982). Apparently, different hues of yellow were obtained from plants of different ages: younger stems gave lighter hues while older stems produced bright yellows. Navajo Indians of the Southwestern United States gathered seeds of C. umbrosa and made them into soup or stew (Castetter 1935). Paiute Indians used Cuscuta spp. as a contraceptive, the plant being known as "woman without children" (Moerman 1977). Maidens of Pawnee Indians used $C$. gronovii to determine the seriousness of a suitor: "A girl having plucked a vine, with the thought of the young man in mind tossed the vine over her shoulder, into the weeds of host species of this dodder [...]. The second day after she would return to see whether the dodder had attached itself and was growing on the host. If so, she went away content with full assurance of her lover's sincerity and faithfulness" (Gilmore 1914).

Gronovius (1762) mentioned first from Virginia a Cuscuta species with "floribus pedunculatis" and stems 


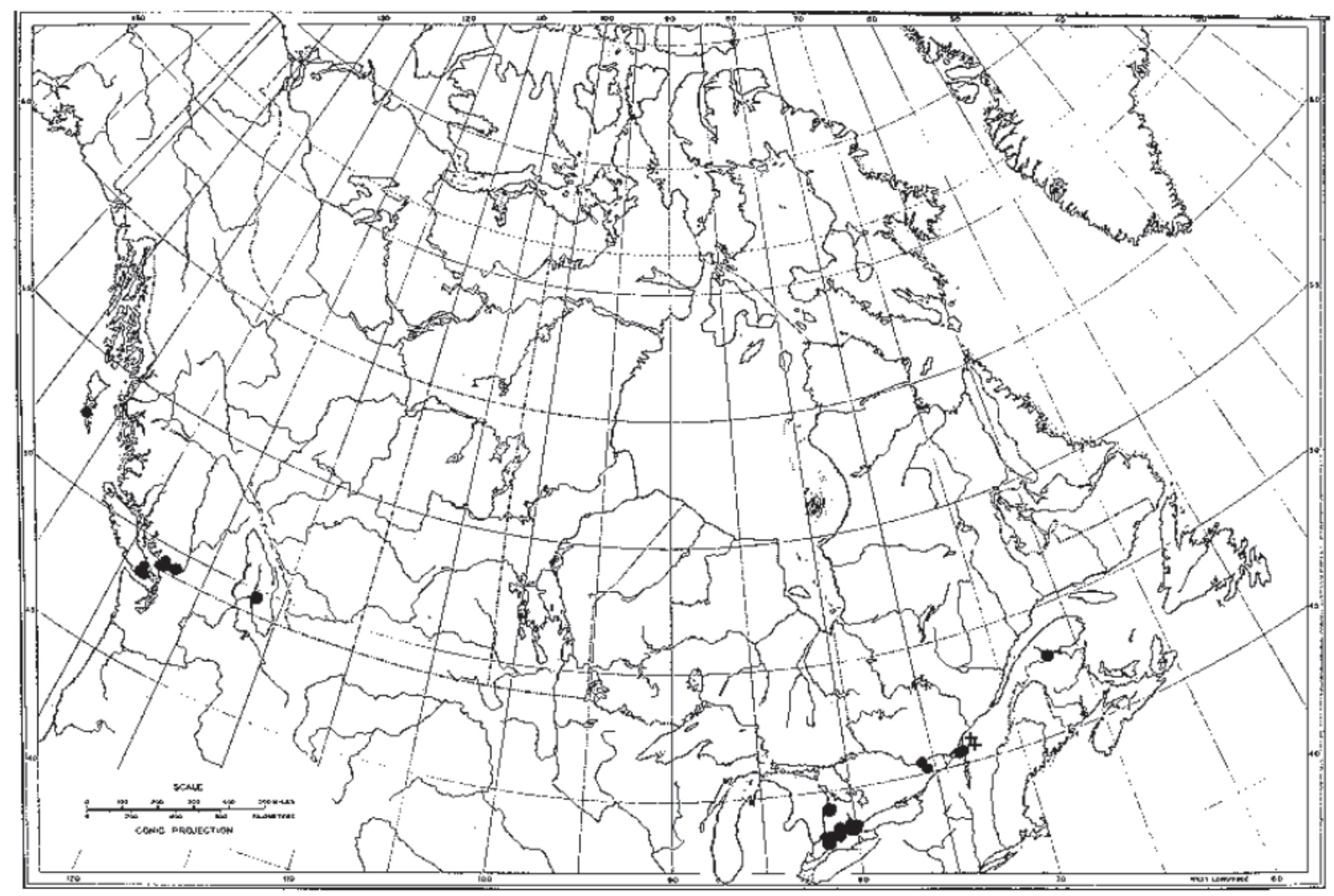

Fig. 5. Distribution of Cuscuta epithymum (dots) and C. epilinum in Canada (crosses). [ACAD, ALTA, DAO, HAM, MT, MTMG, NFLD, NSPM, NY, OAC, QFA, QUE, RBG, SASK, SFS, TUP, UBC, UNB, USAS, UWO, UWPG, WAT, WIN and WIS; herbarium abbreviations according to Holmgren et al. (1990)].

"longis \& fortibus latissime super arbores vel campos se extendes." Later the species was named C. gronovii by Willdenow (Roemer and Schultes 1820).

\section{Growth and Development}

(a) Morphology - Cuscuta spp. embryos and seedlings have no cotyledons. Seedlings have a small, swollen rootlike organ, which persists only a few days after emergence, and a shoot. The basal swollen root-like organ is devoid of a root cap and apical meristems. In C. gronovii it has absorbent hairs (Haccius and Troll 1961; Truscott 1966), while in C. campestris it is smooth (Lyshede 1985). Although it has a transient function in absorbing- and water storage, the structure of this organ does not resemble that of a "normal" root (see below). Removal of the "root" during the germination of C. monogyna did not affect survival of seedlings; however, when cut $2 \mathrm{~d}$ after germination, growth of seedlings was significantly reduced (JianZhong and YangHan 1993). The development of the root-like organ does not involve mitotic divisions, and growth consists only of cell swelling, presumably because of the low level of microtubules present in cells (Sherman et al. 2003). These cells undergo a programmed cell death, and the root-like organ degenerates and dies after 2-5 d (Sherman and Vaughn 2003). Sherman et al. (2003) suggested that this degeneration process may contribute carbon to the continued growth of the seedling shoot. The root-like organ has a single vascular strand centrally located, surrounded by large, thin-walled and vacuolated cells (Lyshede 1985).

Mature stems have a three-layered cortex, longitudinally traversed by short rows, or isolated laticiferous cells (Lyshede 1985). The vascular tissue of stems is centrally located and consists of a few primary collateral bundles with small vessels and tube elements (Lyshede 1985). Articulated multinucleate laticifers are located at the periphery of the vascular cylinder. Rudimentary leaves have a very simple structure with no (Lyshede 1985) or very little vascular tissue (Metcalfe and Chalk 1957), and a thin homogenous mesophyll.

The growth of stems is indeterminate and the overall size of Cuscuta plants greatly depends on the species and the compatibility with the host and its vigor. In turn, the latter depends on the environmental conditions. Relationship with the host may vary from total incompatibility (e.g., with plants from Poaceae), to subtle degrees of tolerance. These may depend on the species, population or even the individuals that participate in the host-parasite relationship. Koch et 
al. (2004) reported that the dry weight of $C$. campestris was significantly higher when parasitizing on Trifolium resupinatum L. than on $T$. alexandrinum L. and Daucus carota. A single Cuscuta spp. plant can simultaneously parasitize several hosts that belong to the same or different species. Cuscuta campestris grown on two hosts of $T$. resupinatum accumulated more dry weight, carbon and nitrogen than when parasitizing two D. carota plants (Koch et al. 2004). When sequentially parasitizing on $T$. resupinatum and D. carota, C. campestris grew larger when the first host was the former, rather that the latter species (Koch et al. 2004). Kelly and Horning (1999) found that Cuscuta attenuata Waterfall achieved a greater stem volume when infesting two hosts of differing species, than two hosts of the same species. Koskela et al. (2002) reported that individuals of $C$. europaea L. growing on female plants of Urtica dioica L. had a higher biomass compared with those infesting male plants. Cuscuta campestris grew significantly larger on older plants of Trifolium resupinatum than on young plants of the same species (Koch et al. 2004).

In developing seedlings, resources are allocated to the growing shoots, as well as to the process of attachment and penetration of the host. Shoots grow very rapidly, $2 \mathrm{~mm}$ in $1 \mathrm{~h}$ (Lyshede 1985), or up $8 \mathrm{~cm}$ in $24 \mathrm{~h}$ (Dawson et al. 1984; Lyshede 1985; Panda and Choudhury 1992). Total length of stems reached almost $750 \mathrm{~m}$ in mature plants of $C$. polygonorum Engelm. (Dean 1942).

The presence of two branching patterns of Cuscuta stems has been documented (Dawson 1984). In C. campestris, the main and secondary stems grow continuously and never twine around the host. Instead, tendril-like branches produced from buds located in the axils of the rudimentary leafscales, fix the parasite to the host. In $C$. gronovii the main stem twines around the host forming haustoria and no tendril-like axillary branches are generated.

The thickness of stems is variable within the same species, or even plant (Yuncker 1921), and it is an indicator of resource availability (Kelly 1994). Growing stems of different ages on the same plant interconnect between themselves through haustorial connections, a phenomenon known as self-parasitism (Dawson et al. 1994). As a result, the plant becomes a complex tri-dimensional network. Lyshede (1985) suggested that the transport distances within the same plant may be reduced in this way.

Embryological data (Johri 1987; Johri et al. 1992) Cuscuta spp. pollen grains are usually 2-celled, but sometimes 3-celled. Pollen grains are spherical to ovoid, with 2 to 6 germination pores (Fig. 2B). Compound pollen grains were reported in $C$. epithymum. Placentation is basal. Ovules are two per locule, ascending, anatropous, unitegmic and tenuinucellate. Embryo-sac development is of the Polygonum- or Allium type, and both may be present in the same species. The endosperm is nuclear, and formation of walls centripetal. Embryogeny is unique among dicotyledons and results in a mature coiled embryo without a radicle and cotyledons, consisting mostly from the hypocotyl.

Mature seeds have a multi-layered seed coat consisting of an epidermis, usually with two palisade layers and 2-4 parenchimatous layers (Tiagi 1951; Lyshede 1984, 1992). A striking feature of the seed coat epidermis is that when seeds dry out, the outer cell walls cells invaginate, which cause the seed surface to become alveolate (Fig. 2 C-F) (Lyshede 1984; Knepper et al. 1990). Water uptake induces bulging of the invaginated epidermal walls, and epidermis cells become swollen, papillose (Lyshede 1984). The seed epidermis contains starch and pectic substances, the latter becoming mucilaginous as seeds absorb water (Grubert 1974; Lyshede 1984).

Growth of seedlings, contact with the host and induction of prehaustoria - The radicle-like organ emerges through the micropyle and assumes a clavate shape. Because the plumule remains enclosed in the seed, the shoot has a characteristic loop-shape when it emerges from the soil (Kuijt 1969; Dawson et al. 1994). The middle portion of the shoot continues to grow and soon the seedling straightens itself, discarding the empty seed coat. The young shoot begins to move in an ascendant and counterclockwise (dextral) direction (Kuijt 1969; Lyshede 1985; Dawson et al. 1994), describing irregular arc-shaped movements (Lyshede 1985). The apical loop of C. gronovii and C. planiflora Ten. seedlings did not open, and seedlings did not nutate in darkness (Kujawski and Truscott 1974; Orr et al. 1996b). Orr et al. (1996b) reported reversible changes from negative to positive gravitropism under cyclical treatments with red and far-red light, suggesting the involvement of phytochrome action during this phase.

Experiments have indicated that Cuscuta spp. seedlings have the capacity to selectively forage into plant communities. They can sense and orient themselves towards green canopies, and they can choose the most suitable host species or age (Fritsché et al. 1958; Lyshede 1985; Kelly 1990, 1992; Orr et al. 1996a; Koch et al. 2004). Compatible host species only 3 wk old were avoided by the searching shoots, which reoriented toward bigger plants (Fritsché et al. 1958; Lyshede 1985). Cuscuta subinclusa Dur. \& Hilg. preferred healthy, green, fertilized and mature plant hosts over yellow, diseased or underdeveloped plants (Kelly 1990, 1992). This shows not only the capacity to detect nearness of other plants, but also an "intelligent choice and intention" as well (Trewavas 2003). Initially, this foraging behavior was explained as a chemotropism (Bünning and Kautt 1956) or hydrotropism reaction (Kuijt 1969). Now it is known that seedlings are phototropic toward low red/far-red ratios (Orr et al. 1996a), and that growth and coiling of Cuscuta spp. shoots are under phytochrome control. Seedlings moved toward unilateral white and blue light in darkness, or toward unilateral far-red light with a background of white light (Spisar 1910; Orr et al. 1996a). A negative phototropic reaction of seedlings was observed to unilateral red or far-red light in darkness (Orr et al. 1966a). If no host is present in the vicinity, seedlings will twine indiscriminately around any inanimate object (Dawson et al. 1994). In this way, there is a chance of using this support as a ramp toward a suitable host. Holm et al. (1997) noted that in field crops, Cuscuta spp. may use weeds as a primary host, and then move to cultivated plants. A shoot of $C$. gronovii can wind tightly up to three coils around the host within $5 \mathrm{~h}$ of contact 
(Dean 1937). Twining can occur only around vertically oriented shapes (innate or alive) (Tsivion 1979; Dawson et al. 1994). The length of seedling shoots depends on the species, from $5-10 \mathrm{~cm}$ in C. campestris to $15-35 \mathrm{~cm}$ in $C$. gronovii (Parker and Riches 1993).

The mechanism of attachment and the development of haustoria have been studied in detail from a structural perspective (Kuijt and Toth 1976; Lee and Lee 1989; Dawson et al. 1994; Vaughn 2002, 2003). Haustoria develop on the inner (concave) side of the stem coils and their part that will remain external to the host is called prehaustorium ("upper haustorium"-Lee and Lee 1989; or "adhesive disk"Dawson et al. 1994). The prehaustorium develops endogenously from a disk-like meristem located within the cortex, close to the vascular bundles (Dawson et al. 1994). Its epidermis cells dedifferentiate and become very rich in cytoplasm. Some of the epidermal cells elongate and form secretory trichome-like structures (Dawson et al. 1994; Vaughn 2002). The cell walls of these secretory trichomes are elastic and allow prehaustoria to follow closely, often through invagination, the shape of stem and micro-outgrowths of the host epidermis (e.g., hairs). Vaughn (2002) suggested that the considerable elasticity of trichome cell walls may be the result of osmiophilic particles, which form cell-wall-loosening complexes. In addition, trichomes secrete an electron-opaque cement consisting of pectins, which fills the host-parasite interface (Dawson et al. 1994; Vaughn 2002). Trichomes ensure the tight contact and adhesion of the parasite to the host but they were never observed to penetrate the tissues of the latter (Dawson et al. 1994).

The prehaustorium in Cuscuta spp. investigated here can reach about $1 \mathrm{~mm}$ long. Development of prehaustoria may occur even in the absence of a host (Tsivion 1978; Tada et al. 1996; Ihl and Wiese 2000), or in the presence of inert materials such as glass (Rath and Mohanty 1987; Tada et al. 1996), cotton strings (Tsivion 1978), filter paper (Fritché et al. 1958), sheets of plastic (Beliz 1986) or acrylic rods (Tada et al. 1996). However, twining around the host does not necessarily lead to initiation of prehaustoria (Furuhashi et al. 1995). The coiling action and the initiation of prehaustoria are suppressed under darkness, white fluorescent and red light conditions, and they are induced by far-red and/or blue light and tactile (mechanical, thigmotropic) stimuli (Zimmerman 1962; Lane and Kasperbauer 1965; Furuhashi et al. 1995, 1997; Tada et al. 1996). This would explain why seedlings of $C$. campestris that emerged under an established alfalfa crop had their attachment to host reduced by 90\% (Dawson 1966). Blue light was found to be more effective in inducing coiling than far-red light (Furuhashi et al. 1995; Haidar et al. 1997). Treatments with mixtures of ultraviolet/far-red, blue/far-red, red/far-red light determined both the twining and prehaustoria initiation (Furuhashi 1995; Haidar et al. 1997). Blue light at photon fluxes lower than 1 $\mu \mathrm{mol} \mathrm{m} \mathrm{m}^{-2} \mathrm{~s}^{-1}$ promoted neither coiling nor initiation of prehaustoria (Haidar et al. 1997). The effect of far-red light was completely reversed by a red light treatment (Tada et al. 1996; Furuhashi et al. 1997; Haidar et al. 1997). The action spectrum for induction of prehaustoria had a pronounced peak near $740 \mathrm{~nm}$ and a small peak at $420 \mathrm{~nm}$, while rever- sal of prehaustoria induction had major a peak at $660 \mathrm{~nm}$ and a minor peak at $380 \mathrm{~nm}$ (Furuhashi et al. 1997; Haidar et al. 1997).

It has been suggested that coiling and induction of prehaustoria are under the control of two classes of photoreceptors: phytochromes (photoreceptors of red/far-red light) and cryptochromes (photoreceptors of blue/ultraviolet light) (Haidar 2003). Chryptochromes interact synergistically with the Pr (red light absorbing) form of phytochrome, and antagonistically with Pfr form in mediating initiation and coiling of prehaustoria (Haidar 2003). Phytochrome B (Furuhashi et al. 1997) or phytochrome A (Haidar et al. 1998) may be involved. Tactile stimulation determined twining and prehaustoria initiation in blue and a mixture of blue/far-red light, but not in darkness or fluorescent white light (Tada et al. 1996; Haidar et al. 1997). Coiling and development of prehaustoria occurred in the presence of cytokinins or zeatin, whereas indole-3-acetic acid (IAA) and abscisic acid (ABA), or their combination, had an opposite effect (Tsivion 1978; Rajagopal et al. 1988; Haidar et al. 1998; Ramasubramanian et al. 1988). Zeatin had a synergistic effect with far-red light but not with red light (Haidar et al. 1998). Ethylene had no effect on coiling and development of prehaustoria development (Haidar et al. 1998). Mechanical stimulation induced haustoria development even in the absence the hormones (Ihl and Wiese 2000).

The molecular mechanisms that govern the development of prehaustoria require further research. Several putative parasitism-specific cDNAs were isolated (Borsics et al. 1999; Borsics and Lados 2001). Two genes from cytokinin-induced haustoria have been cloned and sequenced: a cDNA encoding a hybrid Pro-rich protein (HyPRP) (Subramaniam and Mahadevan 1994) and a cDNA coding for cytocrome b5 (Subramaniam et al. 1994). Tada et al. (2000) reported that the down regulation of a low-molecular-weight heat shock protein (CJHSP17) may be involved in the haustorium development.

Seedlings that do not attach themselves to a host during the autotrophic stage die thereafter. Survival periods reported for seedlings in the absence of a host vary from $8 \mathrm{~d}$ in $C$. campestris (Sitkin 1976) to $7 \mathrm{wk}$ in C. gronovii (Spisar 1910). Taking into account that the root-like organ functions only a few days during the emergence (JianZhong and YangHan 1993), the survival of young Cuscuta spp. represents a remarkable adaptation. Seedlings are succulent and relatively resistant to desiccation, apparently because stomata develop only after plants reach the parasitic stage (Lyshede 1985).

Haustoria invasion and connection to the vascular system of the host - Mechanisms of connection to the host have been studied in great detail (Kuijt and Toth 1976; Lee and Lee 1989; Dawson et al. 1994; Vaughn 2002, 2003). After the successful contact and attachment of the parasite, a mass of tissue known as the "inner haustorium" penetrates and invades the host tissue. After 1 or $2 \mathrm{~d}$, epidermal cells of the inner haustorium began to elongate and form the "searching hyphae." These unicellular formations advance toward the vascular bundles of the host. Within compatible hosts, 
searching hyphae may extend 800 to $2000 \mu \mathrm{m}$ before they contact phloem or xylem cells (Dawson et al. 1994; Vaughn 2003). The inter- and intracellular advance of hyphae through the host is both a mechanical and enzymatic process (Dawson et al. 1994). When intracellular, hyphae induce the host to synthesize a new cell-wall around the cells of the advancing hyphae. The result is a chimeric wall crossed by plasmodesmata, which belongs to both species. This chimeric wall is rich in pectins and has a different composition from the cell walls of both the host and the parasite (Vaughn 2003). Apparently, its role is to minimize the injury produced by invasion, since no typical wound responses (e.g., production of callose) have been observed (Vaughn 2003). Additionally, the inter-specific plasmodesmata, which were observed to be more frequent toward the tip of growing hyphae, may represent the channels of an unknown molecular communication between the host and the parasite (Vaughn 2003).

Searching hyphae connect both to the xylem and the phloem of the host, but some may end blindly in the parenchyma. The xylem connection is almost open because only a pit membrane separates the two systems. The phloem connection is more complex: searching hyphae develop terminal digitiform structures and become "absorbing hyphae". The finger-like protrusions of a single absorbing hyphae may become attached to several (phloem) sieve elements. At the host-parasite interface, the absorbing hyphae develop extensive wall-ingrowths, characteristic to transfer cells. In addition, their cytoplasm develops a smooth endoplasmic reticulum network (Dörr 1990; Dawson et al. 1994).

Total and partial incompatibility between host and parasite - Successful contact and initial penetration of haustoria does not necessarily imply a successful subsequent parasitizing process (Dawson et al. 1994; Christensen et al. 2003). Cuscuta spp. may develop poorly or not at all on certain host species, populations or even individuals. Different degrees of incompatibility arise when the host is capable to defend itself by preventing the haustoria either to reach vascular bundles, or to become functional. For example, layers of lignified or water-storage tissue, present outside the vascular cylinder of the host, may passively delay or prevent the advancement of searching hyphae (Dawson et al. 1994; Sahm et al. 1994). In addition, some host species are capable of actively defending themselves by developing novel barrier tissues, by deposition of newly formed wall material against advancing hyphae, or by producing phytoalexins or other inhibitors (Dawson et al. 1994; Sahm et al. 1995; Singh and Singh 1997; Dhopte 1998; Bringmann et al. 1999; Werner et al. 2001; Christensen et al. 2003).

(b) Perennation-Cuscuta spp. are known as annuals. However, some species when growing on perennial hosts were observed to induce formation of galls, in which parasitic tissue overwinters (e.g., C. gronovii and C. epithymum). New Cuscuta plants regenerate from these embedded parasitic tissues in the next spring (Dean 1937, 1954; Truscott 1958). The procambium and phloem of haustoria that remain in the host produce a "mass of callus-like tuber- cle parenchyma" from which news shoots will differentiate (Truscott 1958). This "tubercle parenchyma," and the subsequent steps in regeneration resemble the somatic embryogenesis in vitro from callus observed by Bakos et al. (2000) in $C$. epithymum. In such a case, the plants can be considered perennial. The phenomenon was observed as early as 1868 by Kuhn on $C$. epithymum parasitizing clover (Trifolium spp.) and alfalfa (Medicago sativa) in Germany (see also Dean 1937).

(c) Physiological data

Solute flux into Cuscuta spp..- Assimilate transport in Cuscuta spp. has been reviewed by Dawson et al. (1994). In seedlings, ${ }^{14} \mathrm{CO}_{2}$-labeled assimilates and ${ }^{32} \mathrm{P}$-isotope absorbed from soil were allocated and translocated only to the growing tips. In plants attached to the host, labeledsucrose accumulated more in the terminal and axillary buds (Dawson et al. 1994). The haustoria create a biochemical continuum between the parasite and its host. Numerous experiments with labeled assimilates have shown an intensive transfer from the host to the parasite (Dawson et al. 1994; Jeschke et al. 1994; Jeschke and Hilpert 1997). Parasitizing plants of Cuscuta spp. act like a "supersink" of their host because they can overcome and redirect the normal solute flux toward other powerful sinks of the host (e.g., the fruits) (Dawson et al. 1994). This induces an increase of the photosynthetic rate in the host (Jeschke et al. 1994; Jeschke and Hilpert 1997). Although the parasite establishes both connections at phloem and xylem levels, Cuscuta spp. are "phloem feeders" since this route supplies the majority of nutrients (Fer 1981; Fer et al. 1987; Dawson et al. 1994; Hibberd and Jeschke 2001). In addition to the primary metabolic compounds (Dawson et al. 1994), xenobiotics (Haupt and Newmann 1996), secondary products such as alkaloids (Czygan et al. 1988; Bäumel et al. 1993, 1994) and cardenolides (Rothe et al. 1999) are also translocated via phloem from the host. The content of minerals in Cuscuta spp. plants and their hosts has been reviewed by Dawson et al. (1994). Heavy metals translocated, such as $\mathrm{Hg}, \mathrm{As}, \mathrm{Pb}, \mathrm{Cu}, \mathrm{Cd}$ and $\mathrm{Cr}$, decreased the Hill reaction activity, protein content and dry mass at doses higher than $0.5 \mu \mathrm{g}$ $\mathrm{mL}^{-1}$ (Jana and Bhattacharjee 1988). Herbicides are also readily translocated by the parasite (Bewick et al. 1991; Nir et al. 1996; Nadler-Hasar and Rubin 2003).

Although the transfers across haustoria are mostly unidirectional, from the host to the parasite, some biochemical messages may travel in the other direction as well. The ultrastructural interface between parasite and host (see Section 7a) suggests an active apoplastic transfer of solutes (Tsivion 1978; Wolswinkel and Ammerlaan 1983; Dawson et al. 1994; Jeschke et al. 1994). In addition, Cuscuta spp. are efficient vectors for viruses and mycoplasmas (see section $13 \mathrm{~b}$ ), requiring the presence of a symplastic continuum between host and parasite. Evidence of a functional symplastic route and the capacity for macromolecular exchange were provided by the transfer of green fluorescent protein from the host to the parasite (Haupt et al. 2001). Hibberd and Jeschke (2001) suggested that Cuscuta spp. may use both symplastic and apoplastic pathways for solutes and 
macromolecular transfer, but the physiological mechanism for these processes is unknown.

Photosynthesis - Cuscuta spp. are considered holoparasites (Dawson et al. 1994). Jeschke et al. (1994), Jeschke and Hilpert (1997) reported that C. reflexa derived more than $99 \%$ of its carbon and $93 \%$ of its nitrogen from the host. However, prior to the contact with the host, seedlings of Cuscuta spp. are autotrophic (although requiring the resources from endosperm). Even during parasitizing stages some species possess a low photosynthetic capacity. Cuscuta campestris and $C$. reflexa grown in vitro were capable of flowering or even fruiting (Loo 1946; Baldev 1959; Malik and Singh 1980). Most of the Cuscuta spp. investigated [see the exceptions from van der Kooij et al. (2000)] possess small amounts of chlorophyll (Zimmerman 1962; Panda and Choudhury 1992; Dinelli et al. 1993; Dawson et al. 1994; Choudhury and Sahu 1999; van der Kooij et al. 2000; Sahu and Choudhury 2000). Both chlorophyll a and b are present in normal proportions, similar to those of autotrophic members of Convolvulaceae (Dinelli et al. 1993; Dawson et al. 1994; Choudhury and Sahu 1999; van der Kooij et al. 2000). The chlorophyll a:chlorophyll b ratio is higher in Cuscuta spp. plants grown under natural light than in plants kept under low irradiance conditions, suggesting that photodestruction of chlorophyll b occurs in the latter condition (Choudhury and Sahu 1999). The total chlorophyll content in C. campestris increased from germination and reached a maximum at flowering (Dinelli et al. 1993). Carotenoid pigments, such as $\alpha$-, $\beta$-carotene and xanthophylls are also present in amounts that are comparable to those of autotrophic plants (MacLeod 1961a, b). Weinberg et al. (2003) studied the effect of herbicides that inhibit carotenoid biosynthesis in $C$. campestris. Because depletion of $\beta$-carotene was associated with the destruction of amyloplasts and the decline in starch content, it was suggested that carotenoids may play a role in maintaining the amyloplast membrane (Weinberg et al. 2003).

A low photosynthetic capacity was demonstrated in several Cuscuta spp. using chlorophyll fluorescence, light-driven electron transport and ${ }^{14} \mathrm{CO}_{2}$ (Panda and Choudhury 1992; Dawson et al. 1994; Hibberd et al. 1998; Choudhury and Sahu 1999; Sherman et al. 1999; van der Kooij et al. 2000). Different Cuscuta spp. exhibit a wide range of photosynthetic capacities, which suggest a gradual evolutionary reduction of the photosynthetic apparatus from hemi- to holoparasitism. Some species have intact plastids, but a low photosynthetic activity (e.g., C. reflexa). Some show alterations at the ultrastructural level of plastids (e.g., $C$. campestris and $C$. gronovii), others have modifications at the level of plastid transcription (e.g., C. grandiflora M. Bieb.), and finally, some have lost the $r b c \mathrm{~L}$ gene (e.g., $C$. odorata Ruiz \& Pav.) (Machado and Zetsche 1990; van der Kooij et al. 2000). The study of the sequence and promoter structure of the gene rrn16 coding for the ribosomal $16 \mathrm{~S}$ rRNA showed that in "green" species (e.g., C. reflexa) plastid transcription is initiated from a functional plastid-encoded RNA polymerase (PEP) promoter, which is missing in other species (e.g., C. gronovii) (Krause et al. 2003). The loss of the promoter was associated with the loss of two genes (rpo $A$ and $r p o B$ ) that encode subunits of PEP (Krause et al. 2003).

When present (e.g., C. reflexa), the photosynthetic metabolism is highly localized in a layer of cells adjacent to the vascular bundles (topographically equivalent to the starch sheath present in many dicotyledons) (Hibberd et al. 1998). Since it is unlikely that external $\mathrm{CO}_{2}$ can diffuse to this layer of cells, it was proposed that $\mathrm{CO}_{2}$ for carbon assimilation is derived from internally respired $\mathrm{CO}_{2}$ (Hibberd et al. 1998).

Nitrogen metabolism - Seedlings of Cuscuta spp. can absorb and presumably assimilate nitrogen from ammonium sulfate, potassium nitrate and ammonium nitrate (Srivastava and Chauhan 1977). However, when attached, Cuscuta spp. depend on the organic nitrogen that they translocate from the host (Jeschke et al. 1994; Jeschke and Hilpert 1997). Translocation of labeled amino acids and amides from the host to the parasite was recorded (Fer 1976; Wolswinkel et al. 1984). Nitrogen metabolism during parasitizing stage was studied in C. campestris and C. reflexa (MacLeod 1963; Srivastava and Dwivedi 2003). Under field conditions, ammonia is assimilated to glutamate only by glutamate dehydrogenase (GDH pathway), as evidenced by the low levels of GDH found. The study of callus cultures of $C$. reflexa revealed the presence of $\mathrm{GDH}$, but also of the enzymes glutamine synthetase (GS) and glutamate oxoglutarate aminotransferase (GOGAT). The latter two enzymes realize the primary pathway for ammonia assimilation in autotrophic plants (Srivastava and Dwivedi 2003). Apparently, because of the ability to take up the reduced form of nitrogen from the host, Cuscuta spp. have lost the ability to assimilate inorganic forms of nitrogen (Lea and Steward 1978). It is not clear how much of this capacity is lost ontogenetically and phylogenetically. As in the case of the photosynthetic apparatus (see above), it is possible that different species may exhibit different levels of reduction in their capacity to metabolize nitrogen. The mineral nutrition of Cuscuta spp. has been reviewed by Dawson et al. (1994).

Transpiration of Cuscuta spp. is said to be reduced (Fer 1984) and is associated with a low density of stomata (e.g., 2 stomata $\mathrm{mm}^{-2}$ in $C$. reflexa), which differentiate after parasitic stage is reached (Lyshede 1985).

The fleshy mature stems of Cuscuta spp. function as storage organs. They accumulate starch, minerals and phytic acid (a reservoir of phosphate) (Dawson et al. 1994; Weinberg et al. 2003). In this way, the parasite may complete its life cycle, even if the host plant has died (Wolswinkel 1974; Singh et al. 1963; 1968).

(d) Phenology - Germination of Cuscuta spp. occurs in southern Canada from the mid-May to mid-June. Based on information collected from herbarium specimens, flowering of $C$. campestris begins around mid-July, and that of $C$. gronovii, $C$. epilinum and $C$. epithymum in August. Flowering and fruiting extend throughout the rest of the growing season, due to the indeterminate growth pattern.

(e) Mycorrhiza - Cuscuta pentagona (C. campestris?) parasitizing vesicular arbuscular (VAM)-symbiotic Abutilon 
theophrasti Medic. had a growth rate 3.4 times greater than when the host was nonmycorrhizal (Sanders et al. 1993). Khalid and Iqbal (1996) reported that arbuscular mycorrhizae (AM)-inoculated seeds of $C$. reflexa produced a network of hyphae, arbuscules and vesicles on the underground parts of seedlings within only $5 \mathrm{~d}$ after sowing. Spores of two or three Glomus spp. were observed. AM seedlings had a significant increase in biomass and longevity compared to noninoculated seedlings. These results suggests that mycorrhiza may allow Cuscuta spp. seedlings to survive longer before establishing the haustorial connection with host. Also, the increased fitness resulting from the mycorrhizal relationship may enhance the chances of successful contact with the host.

\section{Reproduction}

(a) Floral biology - Flowers and inflorescences have been described in Section 2b. A unique feature of Cuscuta flowers is the presence of the infrastaminal scales (also called "hypostaminal scales" or "corolla appendages"). The origin of these formations has been diversely interpreted: as dilatations of lowermost part of staminal filaments, as staminodes or even as duplications of petals (Yuncker 1921; Musselman 1986; Gandhi et al. 1987). More-recent studies showed that infrastaminal scales are initiated at the base of stamens after the other floral organs had been initiated (Kuoh and Liao 1993; Prenner et al. 2002). Knuth (1899, cited in Yuncker 1921) suggested infrastaminal scales may have a protective role. In this respect, Musselman (1986) observed that the scales cover the ovary in young flowers of $C$. campestris and $C$. gronovii but as the flowers grow older, scales separate from the ovary. Scales may have a secretory function (Knepper unpublished, quoted by Musselman 1986) and that they may act as floral nectaries in pollinator attraction (Tiagi 1966; Kuijt 1969). Prenner et al. (2002) observed in C. reflexa that scales hold the nectar secreted by stomata present the base of ovary, and regarded them as secondary nectar receptacles.

Species with small flowers are apparently self-pollinating (Verdcourt 1948; Beliz 1986; Prather and Tyrl 1993; Dawson et al. 1994) and autogamous (Beliz 1986; Musselman 1986). The low pollen/ovule ratio found by Beliz (1986) in C. pentagona (C. campestris ?)(65) supports this idea (see Cruden 1977). Holm et al. (1997) reported that C. epithymum is "normally cross-pollinated but in the absence of insects may be self-pollinated". In Sierra Nevada, Spain, the pollinators of $C$. epithymum were the same insects (mostly Proformica longiseta Collingwood, Formicidae) that pollinated the flowers of the host, Hormathophylla spinosa (L.) Küpfer (Gómez 1994).

Most of the flowers open in the morning, and a few during the day (Beliz 1986; Prather and Tyrl 1993). Anthers dehisce longitudinally and inwardly. Pollen is transferred through direct contact between anthers and stigmas (Prather and Tyrl 1993; personal observation). Cleistogamous flowers (Yuncker 1921; Verdcourt 1948), or mixed cleistogamous and opening flowers in the same cyme, were observed in some species (e.g., in C. pentagona, Beliz 1986), but not in others (C. attenuata, Prather and Tyrl 1993).
Fratianne (1965) found that C. campestris flowered only on flowering hosts, synchronous with the host photoperiodical cycles. Vegetative plants of $C$. campestris did not flower when they were attached to non-flowering plants of soybeans grown under noninductive photoperiods (long-day conditions). A similar synchronicity was also observed between $C$. gronovii and several, but not all the hosts investigated (Denffer 1948). In the latter case, although $C$. gronovii flowered when parasitizing some vegetative hosts (Phytolacca americana L., Oenothera biennis L. and Rudbeckia purpurea L.), the process was considerably delayed (von Denffer 1948). Fratianne (1965) suggested that flowering synchronicity may be determined by an "inhibitor flowering-hormone" produced by the host and traslocated into the parasite. Nevertheless, the existence of this "hormone" has not been proved (Jacob 1966) and the flowering synchronicity was not confirmed in other Cuscuta spp. (e.g., C. salina, Beliz 1986). Cuscuta reflexa grown "in vitro", with no host, flowered in short-day conditions (Baldev 1959). Artificial host defoliation, or its weakening as a result of parasitism, induced flowering of Cuscuta spp. plants (von Denffer 1948; Fratianne 1965; Lyshede 1985). Anthesis lasts 2-7 d, after which corolla withers (Beliz 1986; Prather and Tyrl 1993).

(b) Seed production and dispersal - A single plant of $C$. campestris can produce 16000 seeds (Stevens 1932). The weight of 1000 seeds is $0.775-0.87 \mathrm{~g}$ in $C$. campestris (Stevens 1932; Holm et al. 1997) and $0.3 \mathrm{~g}$ in C. epithymum (Kothekar 1970). The principal means of dispersal of Cuscuta weeds world-wide has been through contaminated seeds of forage legumes (alfalfa, clover and lespedezaLespedeza cuneata (Dumont) G. Don (Dawson et al. 1994). Other means of dispersal are less known. Kuijt (1969) remarked that seed dispersal in this genus is "unspecialized". Lyshede (1984) suggested that wind may play a significant role in dispersal because of the pits present on the seed coat when seeds are dry (see Section 7a). However, Cuscuta seeds do not possess "classical" adaptations for wind dispersal, and the alveolate/papillate seed coat seems more an adaptation related to the germination process. Kuijt (1969) mentioned that seeds remain viable while they pass through the digestive system of sheep. When wetted, seed coat becomes gelatinous and adheres easily to soil particles. Seeds may thus be carried by farm machinery or by birds and animals. Water could play a role in the dispersal of other species (Verdcourt 1948). For example, the seeds of $C$. gronovii and $C$. attenuata float, and these species frequently occur near water. Therefore, although there is no direct evidence of it, seeds may be dispersed in this way as well (Prather and Tyrl 1993).

(c) Seed banks, seed viability and germination - Seeds of Cuscuta may survive at least $10 \mathrm{yr}$ in the field (Menke 1954) and up to $50 \mathrm{yr}$ or more in dry storage depending on the species (Gaertner 1950; Dawson et al. 1984). For example, in dry storage, $C$. campestris may survive 10 to $20 \mathrm{yr}, C$. gronovii up to $30 \mathrm{yr}$, and $C$. pentagona up to $51 \mathrm{yr}$ (Gaertner 1950). Seeds of C. campestris exhibited $50 \%$ germination 
after being submerged in water (in a canal) for $5 \mathrm{yr}$ (Comes et al. 1978). Seed longevity increased with depth of burial, with seeds buried at $50 \mathrm{~cm}$ surviving longer than those buried at $10 \mathrm{~cm}$ (Gruzdev and Prishchepo 1984). There is no information on the seed bank of Cuscuta spp. in agricultural fields but these seed banks are likely quite persistent. Cuscuta gronovii growing in freshwater marshes from Iowa and Michigan, comprised up to $79 \%$ of the seed bank (van der Valk and Davis 1976; Leck and Simpson 1995). Inputs of $C$. gronovii to the seed bank showed year-to-year fluctuations (e.g., from $4.5 \%$ in one year to $50 \%$ in another year). Such fluctuations were correlated with fluctuations in the frequency of its hosts (Leck and Simpson 1995).

Freshly harvested seeds of $C$. campestris are not dormant and may germinate when still in the capsule (Gaertner 1950). However, after a few days, 77 to $95 \%$ of seeds become "hard". Their seed coat dries, becomes hard and impermeable, with the epidermal cells invaginated (see Section 7a), and seeds become dormant (Gaertner 1950; Tingey and Allred 1961; Dawson 1965; Hutchinson and Ashton 1980; Lyshede 1984; Prather and Tyrl 1993). The proportion of "hard" seeds in C. campestris is variable (Parker and Riches 1993), and may reach 95\% (Hutchinson and Ashton 1980). Dormancy in C. campestris was reportedly associated with one of the two outer palisade cell layers of the seed coat (Hutchinson and Ashton 1980; Lyshede 1984). Dormancy was broken when C. campestris seeds overwintered buried at various depths in the field, or when they were stored outdoors at 3 to $8^{\circ} \mathrm{C}$ or at -3 to $0^{\circ} \mathrm{C}$ (Hutchinson and Ashton 1980). This suggests that seeds of Cuscuta spp. from temperate regions undergo a cyclical dormancy/non-dormancy pattern in the soil similarly to other plants (Baskin and Baskin 1998). Breaking down dormancy requires mechanical or chemical scarification (Gaertner 1950; Tingey and Allred 1961; Hutchinson and Ashton 1979; Lyshede 1984). Treatments of C. campestris seeds with sulfuric acid for 30-80 min, or the abrasion between layers of fine sandpaper resulted in over $75 \%$ germination (Gaertner 1950; Ashton and Santana 1976; Kroschel 2001). The optimum temperature for the germination of $C$. campestris is $30-33^{\circ} \mathrm{C}$, the maximum is $36-39^{\circ} \mathrm{C}$, and the minimum is $10-16^{\circ} \mathrm{C}$ (Stojanovic and Mijatovic 1973; Allred and Tingey 1964; Hutchinson and Ashton 1980; Lados 1999; Nojavan and Montakhab 2001).

Optimum germination of C. epithymum is at $26^{\circ} \mathrm{C}$ (Lados 1999). Germination of $C$. campestris in the field occurred after the temperature reached $10^{\circ} \mathrm{C}$ in the soil (Allred and Tingey 1964), or after the 5-d mean temperature reached $18^{\circ} \mathrm{C}$ in the air (Hutchinson and Ashton 1980). The relatively high temperature requirements for germination ensure the emergence of the parasite when potential hosts are already established. Seeds germinate both in dark and light and are stimulated by ammonium sulfate, potassium nitrate and ammonium nitrate (Srivastava and Chauhan 1977). Cuscuta epithymum germinated better at lower $\mathrm{pH}$, whereas $\mathrm{pH}$ had no particular effect on $C$. campestris seeds (Lados 1999). The seed coat of germinating seeds absorbs water and becomes mucilaginous, with the epidermal cells swollen (Lyshede 1985).
Most seedlings of $C$. campestris emerge from the top $3 \mathrm{~cm}$ of soil, with none emerging below $6.5 \mathrm{~cm}$ (Allred and Tingey 1964; Hutchinson and Ashton 1980). Seeds buried on the surface emerged in $3 \mathrm{~d}$, while those at 4-5 cm emerged in $6 \mathrm{~d}$ (Stojanovic and Mijatovic 1973). Better emergence of $C$. campestris in the field was obtained when measures to prevent soil crust formation were taken (Hutchinson and Ashton 1980). Emergence of $C$. epithymum in the field was observed 2 wk after the soil temperature reached $10^{\circ} \mathrm{C}$ (Holm et al. 1997). Using low-temperature thresholds (LTT) of 0 and $3.3^{\circ} \mathrm{C}$, the emergence of $C$. gronovii in Wisconsin was predicted after 161 and 118 growing degree days, respectively (Bewick et al. 1988a). Furthermore, it was predicted that $0.1 \%$ seedlings may emerge in any season at values between 150 and $170 \mathrm{GDD} / 0^{\circ} \mathrm{C}$ or 114 and $122 \mathrm{GDD} / 3.3^{\circ} \mathrm{C}$ (Bewick et al. 1988a). The proportion of seedlings that emerge each year is variable. Allred and Tingey (1964) in Utah found 64\% emergence of $C$. campestris in the first year, and $3 \%$ in the second year. Dawson (1965) reported that only $7 \%$ of the seeds emerged over a period of $2 \mathrm{yr}$ in a greenhouse experiment. Relatively similar results were obtained in California by Hutchinson and Ashton (1980): only $10 \%$ of the C. campestris seeds sown in the field emerged over a period of $5 \mathrm{yr}$. Most of the seedlings (3.2-5.7\%) emerged in the first year. Emergence percentage declined over time and no seedling emerged in the fifth year (Hutchinson and Ashton 1980).

(d) Vegetative reproduction - Fragments of stem can attach themselves and regenerate whole plants (Truscott 1958). Breakage can be the result of the host's growth or it can be produced by animals, humans or farm machinery. The study of $C$. corymbosa Ruiz \& Pavón in the field, showed that natural breakage levels varied between 2 and $66 \%$, and that fragmentation did not impair growth and biomass accumulation of individual plants (Kelly et al. 2001). Another potential way of vegetative spreading of some Cuscuta spp. is through the haustorial tissue surviving in perennial host over the winter (see Section $7 b$ ).

\section{Hybrids}

Although no interspecific hybrids have been described and experimental attempts to produce hybrids have failed (Prather and Tyrl 1993), the possibility of hybridization cannot be excluded (Beliz 1986).

\section{Population Dynamics}

Cuscuta spp. from temperate regions have probably only one generation per year. They can rapidly colonize (see Section 8b) disturbed areas, where they grow in patches. Population dynamics of Cuscuta spp. depend on a series of factors: the population dynamics of their hosts; the capacity of potential hosts to defend themselves, and the environmental conditions. Leck and Simpson (1995), studying the dynamics of vegetation in a fresh water marsh, found that in general C. gronovii was successful in the years when its most important host, Impatiens capensis Meerb., was successful as well. However, in some years successful emergence of the parasite was followed by poor establishment without apparent causes (Leck and Simpson 1995). In some cases, the failure to establish of 
Cuscuta spp. is the result of the total or partial incompatibility between host and parasite (see also Sections 5c, 7a). Some weed species were reported to have an allelopathic action against Cuscuta spp. Extracts of Cynodon dactylon (L.) Pers. and Chenopodium murale L. controlled $83-96 \%$ of the $C$. campestris infesting alfalfa (Habib and Rahman 1988). About 10 species of Chenopodium were observed to inhibit in various degrees the attachment and subsequent growth of Cuscuta spp. (Dawson et al. 1994). Symptoms exhibited by C. campestris after the attachment to Chenopodium album $\mathrm{L}$. were similar to those resulted after treatments with glyphosate (Dawson et al. 1994).

\section{Response to Herbicides and Other Chemicals}

Chemical control methods in various crops have been reviewed in detail by Parker and Riches (1993) and Dawson et al. (1994). Diuron inhibits photosynthesis in Cuscuta spp. but this does not affect plant growth and development (Lane et al. 1965; Dawson 1967). Treatments with herbicides that inhibit carotenoid biosynthesis had a variable efficacy on $C$. campestris (Weinberg et al. 2003). Flurochloridone at $625 \mathrm{~g}$ $\mathrm{ha}^{-1}$ caused a rapid stem bleaching, but plants continued to grow and eventually they recovered fully. Sulcotrione and mesotrione at $250 \mathrm{~g} \mathrm{ha}^{-1}$ also caused stem bleaching, but plants did not recover (Weinberg et al. 2003). The three herbicides caused an accumulation of phytoene and depletion of $\beta$-carotene, which were associated with the destruction of plastids and depletion of starch content in $C$. campestris (Weinberg et al. 2003).

No herbicide-resistant biotypes have been reported in North America for any of the four species (Heap 2002). Cuscuta campestris developed resistance to ALS inhibitors (chlorsulfuron, and sulfometuron-methyl) in Israel in 1994 (Rubin 1995). Resistant plants occurred in a few sites while parasitizing ALS inhibitor resistant Amaranthus blitoides S. Wats. plants (Rubin 1995). Cuscuta campestris is capable to tolerate and recover from high rates of glyphosate and sulfometuron (amino acid bio-synthesis inhibitor herbicides AABI) (Nadler-Hassar and Rubin 2003). The species was reported to be more resistant to $\mathrm{AABI}$ herbicides than the transgenic resistant host crop plants, glyphosate-resistant sugarbeet and cotton, and sulfometuron-resistant tomato.

\section{Response to Other Human Manipulations}

Crop rotation with forage grasses or cereal grains is one of the most efficient cultural ways to control future infestations because Cuscuta spp. do not attack plants from Poaceae. Rotations following infestation with $C$. epilinum should avoid flax or linseed. Crops such as beans, squash, cucumber, cotton and tomato are more or less resistant to $C$. campestris, and they can be used in rotations (Parker and Riches 1993; Dawson et al. 1994). However, there is considerable variation in susceptibility to $C$. campestris. For example, some varieties of tomatoes tend to be resistant to C. campestris, but others are susceptible (Goldwasser et al. 2001). This would explain contradictory reports found in the literature (Dawson et al. 1994).

Planting crops after the germination flush of Cuscuta spp. in the spring, or if possible in autumn, achieves good results
(Dawson 1971). Seedlings of Cuscuta spp. cannot twine and attach themselves if the crop is already well established (see Section 7a). Hand-pulling the parasite together with its host before seeds are set, and burning the plant material are effective means in controlling isolated infestations (Parker and Riches 1993). Shallow harrowing/cultivation applied during the seedling stage of the parasite can be effective in established alfalfa or in row crops such as sugarbeet, carrots and onions (Dawson et al. 1984; Dawson 1987; Dawson et al. 1994). Close mowing of alfalfa after hay harvest at 2-3 $\mathrm{cm}$ proved to be more effective in removing infested stubble than mowing at $10 \mathrm{~cm}$ (Dawson 1987). Flail-mowing and burning with a hand-held propane gas weed burner were equally effective in controlling $C$. indecora infesting alfalfa crops in California, but the latter was more expensive (Cudney et al. 1992). Fire has been commonly used in the United States to control Cuscuta spp. in alfalfa but this method reduces the hay yield (Parker and Riches 1993). Dry heat treatments of $15 \mathrm{~min}$ at $100^{\circ} \mathrm{C}$ were used to decontaminate niger seeds [Guizotia abyssinica (Lf.) Cass.] from the seeds of $C$. campestris and C. indecora (Strasser 1988). Mechanical methods for seed decontamination have been reviewed by Dawson et al. (1994).

Sandler et al. (1997) reported that the application of a 2.5$\mathrm{cm}$ layer of sand reduced the seedling emergence of $C$. gronovii in cranberry bogs, but it did not affect the survival of the parasite. Controlled floods (24-48h) in cranberry bogs reduced the infestation of $C$. gronovii (Sandler and Mason 2004). Solarization of scarified seeds of $C$. campestris with transparent polyethylene during $10 \mathrm{~d}$, resulted in a reduction of the percent of total seed germination (PTSG) by 95\% (Haidar et al. 1999b). Unscarified seeds required $6 \mathrm{wk}$ to obtain a reduction of PTSG by $69 \%$ (Haidar et al. 1999b). Stojsin et al. (1991) reported that the intensity of $C$. campestris damage in a sugarbeet crop depended on the level of mineral fertilization, and the highest attack occurred in non-fertilized plots.

\section{Response to Herbivory, Disease and Higher Plant Parasites}

(a) Mammals - Gómez (1994), in Sierra Nevada, Spain reported that plants of Hormatophylla spinosa infested by $C$. epithymum were avoided by the Spanish ibex (Capra pyrenaica Schinz.), the main herbivore of the former species. If Cuscuta spp. are avoided by herbivores, possibly because of their color, an advantage would be conferred to their hosts, thus influencing the structure of plant communities.

(b) Birds and/other vertebrates - No data.

(c) Insects - Only a few insects attack Cuscuta spp., which is reflected in the scarcity of reports found in the literature. The most important insects associated with Cuscuta spp. are those from the genus Smicronyx, subgenus Smicronyx (Order: Curculionidae). Eleven species of Smicronyx, attack Cuscuta spp. in North America: S. apionides Casey, S. atratus Motschulsky, S. congestus Casey, S. cuscutiflorae Pierce, $S$. defricans Casey, S. interruptus Blatchley, $S$. pacificus Anderson, S. posticus Dietz, S. quadrifer Casey, S. 
sculpticollis Casey, S. tychoides LeConte (Pierce 1939; Anderson 1962, 1970; O'Brien and Anderson 1996). Among these, only three species are known from Canada: $S$. congestus (Manitoba), S. sculpticollis (Ontario and New Brunswick) and S. tychoides (Ontario and New Brunswick) (O'Brien and Anderson 1996). Some species (e.g., S. tychoides and $S$. sculpticollis produce galls on the stems of Cuscuta spp. (Anderson 1962), while others (e.g., S. cuscutiflorae and $S$. defricans) lay their eggs in the ovaries, and larvae feed on the seeds producing probably considerable damage (Pierce 1939). Other insects found on Cuscuta spp. in North America, e.g., Tanaops spp. (Coleoptera: Melyridae), Trichochrous (Coleoptera: Melyridae) and Bruchus spp. (Coleoptera: Bruchidae), were considered flower visitors and pollen feeders (Pierce 1939).

Biological control with insects has been studied mostly in Europe and Asia (Parker and Riches 1993). Some of the 30 species of Smicronyx that infest various Cuscuta spp. have been reported as potential biological control agents (Parker and Riches 1993), but no control methods have been developed so far. Most commonly, adults of Smicronyx spp. lay their eggs in the stems of Cuscuta spp.; the larvae feed inside and produce galls. In Iran, a second generation was observed in S. robustus Faust (Shimi et al. 1995). The adults lay their eggs in the capsules, and the larvae feed on the ovules and seeds producing more damage than the first generation (Shimi et al. 1995).

(d) Other invertebtates - Cuscuta spp. may be attacked by nematodes only during the short seedling phase. However, studies have showed that Cuscuta spp. extract is toxic to nematodes (Mojumder and Goswami 1987; Robinson et al. 1990; Haidar et al. 1999a).

\section{Diseases}

(a) Fungi-Cuscuta pentagona and C. epithymum are hosts of Colletotrichum destructivum O'gara in Oregon (Leach 1958; Shaw 1973). In Wisconsin, C. gronovii is a host of Phomopsis cuscutae H. C. Greene (Greene 1964), Fusarium tricinctum (Corda) Saccardo and an Alternaria spp. (Bewick et al. 1986), and Cuscuta spp. of Phoma spp. (Greene 1953). Alternaria destruens Simmons was recently described from C. gronovii growing in Indiana (Simmons 1998).

Spores of Fusarium tricinctum and an Alternaria spp. isolated from C. gronovii in Wisconsin and applied at $380 \mathrm{~L} \mathrm{ha}^{-1}$ $\left(5 \times 105\right.$ spores $\left.\mathrm{mL}^{-1}\right)$ controlled this species up to $92 \%$ (Bewick et al. 1986). Carrots, cranberries, celery, potatoes and alfalfa were tolerant to both fungi species (Bewick et al. 1986). However, these promising preliminary studies have not been applied into practice. A strain of Colleotrichum destructivum was identified from Cuscuta spp. in Oregon and it was proposed as a potential biological control agent (Leach 1958), but no further research has been undertaken. A commercial product, Lubao No. 1 based on Colletotrichum gloeosporioides f. sp. cuscutae has been developed in China since 1963 to control $C$. chinensis and $C$. australis in soybeans (Zhang 1985; Wan and Wang 1991; Julien 1992). A new strain, Lubao No. 1 S22, was re-isolated to overcome the loss of virulence of the previous strain. The product has been extensively used in China and greater than $85 \%$ control was reported (Gao and Gan 1992, 1993). The fungus produces pathogenic exotoxins that cause lesions on Cuscuta stems (Hui and ShiBin 2002). The product was tested in Arkansas on $C$. campestris growing on a wide range of hosts (Cartwright and Templeton 1989). Except for one population from California, which was killed by the fungus, $C$. campestris was only partially controlled by the mycoherbicide, and the authors concluded that the practical potential of the mycoherbicide in the United States was relatively low under the tested conditions (Cartwright and Templeton 1989). Better results were obtained in Israel, where Cuscuta spp. from 35 cultivars of 19 crop species were completely destroyed by the fungus (Nof et al. unpublished, quoted by Watson et al. 2000). Other preliminary tested biocontrol agents are Fusarium solani (Martius) Saccardo, F. semitectum Berk. \& Ravenel, Alternaria tenuis Nees and Pestalotiopsis guepinii (Desm.) Stey. (their pathogenity decreased in this order) isolated from $C$. reflexa in China (Guo FengGen et al. 1998; Guo FengGen and Li YangHan 2000), and Alternaria cuscuticidae investigated in the former USSR (Volkov 1989).

(b) Bacteria-In Armenia, trichothecin, a metabolite produced by Trichothecium roseum (Pers.:Fr.) Link inhibited the germination of $C$. monogyna, but it was ineffective against 6- to 7-d-old seedlings (Oganyan 1976).

(c) Mycoplasma-like organisms (MLOs) - Cuscuta spp. are a well known vector for mycoplasmas and viruses. The transfer occurs naturally when a Cuscuta spp. plant infests two or more plants (same or different species) and the mechanism has been extensively used for experimentation purposes (Heintz 1989; Carraro et al. 1991; Credi and Santucci 1992; Valencia et al. 1993; Maixner et al. 1994; Dawson et al. 1994; Loi et al. 1995; Marcone et al. 1995. 1997, 1999; Kamiska and Korbin 1999; Kamiska et al. 2001a, b; Scott and Zimmerman 2001). Cuscuta spp. may transfer macromolecular constituents to and from the host.

(d) Viruses - Cuscuta spp. are not mentioned as hosts for viruses in any major virus databases (Zitter 2002; Brunt et al. 2003). However, Cuscuta spp. are well known artificial vectors for numerous viruses (Bennet 1944; Schmelzer 1958; Hosford 1967; Roos and Aldrich 1988; Eppler 1992; Welliver and Halbrendt 1992; Bellardi and Bertaccini 1993; Kumar and Mohan 1994; Subandiyah 1994; Pozzer et al. 1995; Jordá et al. 2001).

\section{ACKNOWLEDGMENTS}

We would like to thank Hillary Sandler and one anonymous reviewers for their criticism and helpful comments on a previous version of this manuscript.

Agha, A. M., Sattar, E. A. and Galal, A. 1996. Pharmacological study of Cuscuta campestris Yuncker. Phytother. Res. 10: 117-120.

Allred, K. R. and Tingey, D. C. 1964. Germination and spring emergence of dodder as influenced by temperature. Weeds 12: $45-48$. 
Anderson, D. M. 1962. The weevil genus Smicronyx in America North of Mexico (Coleoptera: Curculionidae). Proc. US Nat. Mus. 113 (no. 3456): 185-372.

Anderson, D. M. 1970. Dodder weevils in simultaneous association with parasitic plants and their hosts. Science 168: 132-133.

Anis, E., Anis I., Ahmed, S., Mustafa, G., Malik, A., Afza, N., Hai, S. M. A., Shahzad-

ul-Hussan, S. and Choudhary, M. I. 2002. _-Glucosidase inhibitory constituents from Cuscuta reflexa. Chem. Pharm. Bull. 50: $112-114$

Anonymous. 1986. Weeds seed order (SOR/86-836). Department of Justice Canada. [Online] Available: http://laws.justice.gc.ca/en/ S-8/SOR-86-836/173943.html [2004 April].

Aryavand, A. 1987. The chromosome numbers of some Cuscuta L. (Cuscutaceae) species from Isfahan, Iran. Iran. J. Bot. 3: 177-182.

Ashton, F. M. and Santana, D. 1976. Cuscuta spp. (dodder): A literature review of its biology and control. Univ. of California Coop. Ext. Bull. 1880: 1-20.

Bakos, Á., Borsics, T., Toldi, O., Babos, K. and Lados, M. 2000. Evidence for somatic embryogenesis during plant regeneration from seedling-derived callus of dodder (Cuscuta trifolii Bab. et Gibs). Plant Cell Rep. 19: 525-528.

Baldev, B. 1959. In vitro responses of growth and development of Cuscuta reflexa. Phytomorphology 9: 316-319.

Baskin, C. C. and Baskin, J. M. 1998. Seeds. Ecology, biogeography, and evolution of dormancy and germination. Academic Press, Toronto, ON. 666 pp.

Bäumel, P., Jeschke, W. D., Witte, L., Czygan, F. C. and Proksch, P. 1993. Uptake and transport of quinolizidine alkaloids in Cuscuta reflexa parasitizing on Lupinus angustifolius. Z. Naturforsch. 48c: 436-443.

Bäumel, P., Witte, L., Czygan, F. C. and Proksch, P. 1994. Transfer of quinolizidine alkaloids from various host plants of the Fabaceae to parasitizing Cuscuta species. Biochem. Syst. Ecol. 22: 647-656.

Beliz, T. 1986. A revision of Cuscuta sect. Cleistogrammica using phenetic and cladistic analyses with a comparison of reproductive mechanisms and host preferences in species from California, Mexico, and Central America. Ph.D. diss., University of California, Berkeley, CA. 181 pp.

Bellardi, M. G. and Bertaccini, A. 1993. Infezioni da AMV su colture ornamentali e da fiore. Informatore Fitopatologico 43: 11-15 [in Italian, English abstract].

Belyaeva, A. V., Cherkasova, A. P., Shpanova, L. G. and Alfimova, R. A. 1978. Maleic hydrazide against dodder. Sakharnaya Svekla 23: 37-39.

Bennett, C. W. 1944. Studies of dodder transmission of plant viruses. Phytopathology 34: 905-932.

Bewick, T. A., Binning, L. K. and Yandell, B. 1988a. A degree day model for predicting the emergence of swamp dodder in cranberry. J. Am. Soc. Hortic. Sci. 113: 839-841.

Bewick, T. A., Binning, L. K. and Dana, M. N. 1988b. Postattachment control of swamp dodder (Cuscuta gronovii) in cranberry (Vaccinium macrocarpon) and carrot (Daucus carota). Weed Technol. 2: 166-169.

Bewick, T. A., Binning, L. K. and Balke, N. E. 1991. Absorption and translocation of glyphosate by carrot infected by swamp dodder. J. Am. Soc. Hortic. Sci. 116: 1035-1039.

Bewick, T. A., Binning, L. K., Stevenson, W. R. and Stewart, J. 1986. Development of biological control for swamp dodder. Proc. North Centr. Weed Sci. Soc. 41: 24 (Abst.).

Blatter, S. J., Caius, J. F. and Mhaskar, K. S. 1988. Indian medicinal plants. Vol. 3, Bishen Singh Mahendra Pal Singh, Dehra, India. Pp. 1740-1743.
Bork, P. M., Schmitz, M. L., Weimann, C., Kist, M. and Heinrich, M. 1996. Nahua Indian medicinal plants (Mexico): inhibitory activity on NF-B as an anti-inflammatory model and antibacterial effects. Phytomedicine 3: 263-269.

Borsics, T. and Lados, M. 2001. cDNA cloning of a mechanical/abiotic stress-inducible calmodulin-related gene from dodderinfected alfalfa. Plant Cell Environ. 24: 649-656.

Borsics, T., Bakos, Á., Hunyadi, K. and Lados, M. 1999. Investigation of genetic background of plant parasitism in the model system of alfalfa (Medicago sativa) and dodder (Cuscuta trifolii). Növényvédelem 35: 3-8. [in Hungarian, with English abstract].

Bringmann, G., Schlauer, J., Ruckert, M., Wiesen, B., Ehrenfeld, K. and Proksch, P. 1999. Host-derived acetogenins involved in the incompatible parasitic relationship between Cuscuta reflexa and Ancistrocladus heyneanus. Plant Biol. 1: 581-584.

Brunt, A. A., Crabtree, K., Dallwitz, M. J., Gibbs, A. J., Watson, L. and Zurcher, E. J. (eds.) 2003. Plant viruses online. [Online] Available: http://image.fs.uidaho.edu/vide/refs.htm [2003 March].

Bünning, E. and Kautt, R. 1956. Uber den Chemotropismus der Keimlinge von Cuscuta europaea. Biol. Zentbl. 75: 356-359.

Caji, V. and Stjepanovi, M. 1995. Alfalfa seed losses and quality as affected by presence of weed species during processing. Sjemenarstvo 12: 123-134.

Carraro, L., Osler, R., Loi, N. and Favali, M. A. 1991. Transmission characteristics of the clover phyllody agent by dodder. J. Phytopathol. 133: 15-22.

Cartwright, D. K. and Templeton, G. E. 1989. Preliminary evaluation of dodder anthracnose fungus from China as a mycoherbicide for dodder control in the U.S. Proc. Arkansas Acad. Sci. 43: $15-18$.

Castetter, E. F. 1935. Ethnobotanical studies in American Southwest. I. Uncultivated native plants used as sources of food. University of New Mexico Bulletin 266.

Chao S. L., Huang L-W. and Yen H-R. 2003. Pregnancy in premature ovarian failure after therapy using Chinese herbal medicine. Chang Gung Medical Journal 26: 449-452.

Chavan, S. R., Nikam, S. T., Kamath, V. R. and Renapurkar, D. M. 1982. Mosquito larvicidal/insecticidal activity of indigenous plants. Pages 175-179 in K. M. Alexander and R. S. Prasad, eds. Vectors and vector-borne diseases. Proc. All India Symposium. Trivandrum/Kerala State/India.

Choudhury, N. K. and Sahu, D. 1999. Photosynthesis in Cuscuta reflexa: A total plant parasite. Photosynthetica 36: 1-9.

Christensen, N. M., Dörr, I., Hansen, M., van der Kooij, T. A. W. and Schulz, A. 2003. Development of Cuscuta species on a partial incompatible host. Induction of xylem transfer cells.

Protoplasma 220: 131-142.

Comes, R., Bruns, V. and Kelly, A. 1978. Longevity of certain weed and crop seed in fresh water. Weed Sci. 26: 336-334.

Cooke, D. A. and Black, I. D. 1987. Biology and control of Cuscuta campestris and other Cuscuta spp.: a bibliographic review. Technical Paper, South Australian Department of Agriculture 18, Adelaide, South Australia. 33 pp.

Costea, M. and Tardif, F. J. 2004. Cuscuta (Convolvulaceae) The strength of weakness: a history of its name, uses and parasitism concept during ancient and medieval times. Sida 21: 369-378.

Credi, R. and Santucci, A. 1992. Dodder transmission of mycoplasma-like organisms (MLOs) from grapevines affected by a flavescence dorée-type disease to periwinkle. Phytopath. Medit. 31: $154-162$. 
Crins, W. J. and Ford, B. A. 1988. The parasitic dodders (Cuscuta: Cuscutaceae) in Ontario. Can. Field-Nat. 102: 209-215. Cronquist, A. 1988. Evolution and classification of flowering plants. The New York Botanical Garden, Bronx, NY. 555 pp.

Cruden, R. W. 1977. Pollen - ovule ratios: a conservative indicator of breeding systems in flowering plants. Evolution 31: 32-46.

Cudney, D. W., Orloff, S. B. and Reints, J. S. 1992. An integrated weed management procedure for the control of dodder (Cuscuta indecora) in alfalfa (Medicago sativa). Weed Technol. 6: 603-606.

Czygan, F.-C., Wessinger, B. and Warmuth, K. 1988. Cuscuta and its property to take up and to accumulate alkaloids of the host plant. Biochem. Physiol. Pflan. 183: 495-501.

Darbyshire, S. J. 2003. Inventory of Canadian agricultural weeds. Agriculture and Agri-Food Canada, Research Branch, Ottawa, ON. 396 pp. [Online] Available: http://res2.agr.ca/ecorc/weeds_herbes/ title-titre_e.htm [2004 August].

Dawson, J. H. 1965. Prolonged emergence of field dodder. Weeds 13: $373-374$

Dawson, J. H. 1966. Response of field dodder to shade. Weeds. 14: 4-5.

Dawson, J. H. 1967. Soil-applied herbicides for dodder control: initial green-house evaluation. Bull. Wash. Agric. Exp. Stn. 691, 7 pp.

Dawson, J. H. 1971. Establishing alfalfa on dodder infested soil. Weed Sci. 19: 222-225.

Dawson, J. H. 1984. A vegetative character that separates species of Cuscuta. Pages 184-187 in C. Parker, L. J. Musselman, R. M. Polhill, and A. K. Wilson, eds. Proc. 3rd Intern. Symp. on Parasitic Weeds. The International Center for Agricultural Research in the Dry Areas (ICARDA), Aleppo, Syria.

Dawson, J. H. 1987. Cuscuta (Convolvulaceae) and its control. Pages 137-149 in H. C. Weber and W. Forstreuter, eds. Proc. 4th Int. Symp. Parasitic Flowering Plants, Philipps Universität, Marburg, Germany.

Dawson, J. H. 1989. Dodder (Cuscuta spp.) control in established alfalfa (Medicago sativa) with glyphosate and SC-0224. Weed Technol. 3: 552-559.

Dawson, J. H., Musselman, L. J., Wolswinkel, P. and Dörr, I. 1994. Biology and control of Cuscuta. Rev. Weed Sci. 6: 265-317. Dawson, J. H., Ashton, F., Welker, W., Frank, J. and Buchanan, G. 1984. Dodder and its control. USDA Farmers Bull. 2276, 24 pp.

de Sahagún, F. B. (ca. 1499-1590) 1950-1982. Florentine Codex: General history

of the things of New Spain. Books 1-12. Translated by A. J. O. Anderson and C. E. Dibble. School of American Research and University of Utah, Salt Lake City, UT.

Dean, H. L. 1937. Gall formation in host plants following haustorial invasion by Cuscuta. Am. J. Bot. 24: 167-173.

Dean, H. L. 1942. Total length of stem developed from a single seedling of Cuscuta. Proc. Iowa Acad. Sci. 49: 127-128.

Dean, H. L. 1954. Dodder overwintering as haustorial tissues within Cuscuta-induced galls. Proc. Iowa Acad. Sci. 61: 99-106.

Dhopte, A. M. 1998. Inhibition of Cuscuta growing on Parthenium. Ann. Plant Physiol. 12: 80-81.

Dinelli, G., Bonetti, A. and Tibiletti, E. 1993. Photosynthetic and accessory pigments in Cuscuta campestris Yuncker and some host species. Weed Res. 33: 253-260.

Dörr, I. 1990. Sieve elements in haustoria of parasitic angiosperms. Pages 239-253 in H.-D Behnke and R. D. Sjölund, eds. Sieve elements: comparative structure, induction and development. Springer, New York, NY.

Engelmann, G. 1859. Systematic arrangement of the species of the genus Cuscuta with critical remarks on old species and descriptions of new ones. Trans. Acad. Sci. St. Louis 1: 453-523.
Eppler, A. 1992. Untersuchungen zur Übertragung von Hopfenvirusen durch Seiden, Cuscuta spp. Mededelingen van de Faculteit Landbouwwetenschappen, Universiteit Gent 57: 341-349.

Evers, R. A. and Link, R. P. 1972. Poisonous plants of the Midwest and their effects on livestock. Univ. Illinois Spec. Publ. 24, $165 \mathrm{pp}$.

Feinbrun, N. 1970. A taxonomic review of European Cuscutae. Isr. J. Bot. 19: 16-29.

Fer, A. 1976. Absorption, translocation and metabolism of phosphates by Cuscuta gronovii Willd. seedlings during their preparasitic stage. Biol. Plant. 18: 450-459.

Fer, A. 1981. Research on the pathway of transport involved in the nutrition of a parasite phanerogamous. A study on isolated leaves parasitized by Cuscuta. Physiologie Vegétalé 19: 177-196 [in French].

Fer, A. 1984. Physiological approach to the chemical control of Cuscuta: experiments with 14C-labelled herbicides. Pages 164-174 in C. Parker, L. J. Musselman, R. M. Polhill, and A. K. Wilson (eds.), Proc. 3rd Intern. Symp. on Parasitic Weeds. The International Center for Agricultural Research in the Dry Areas (ICARDA), Aleppo, Syria.

Fer, A., Bock, F. de, Renaudin, S., Rey, L. and Thalouarn, P. 1987. Relations trophiques entre les Angiospermes parasites et leurs hotes respectifs. II. Voies de transport et mecanismes impliques dans le transfert des substances trophiques a l'interface hote-parasite. Bull. Soc. Bot. Fr. Actual. Bot. 134: 109-120.

Fogelberg, S. O. 1938. The cytology of Cuscuta. Bull. Torrey Bot. Club. 65: 631-645.

Fratianne, D. G. 1965. The interrelationship between the flowering of dodder and the flowering of some long and short day plants. Am. J. Bot. 52: 556-562.

Fritsché, E., Bouillenne-Walrand, M. and Bouillenne, R. 1958. Quelques observations sur la biologie de Cuscuta europaea L. Acad. Roy. Belg. Bull. Cl. Sci. 44: 163-197.

Furuhashi, K., Kanno, M. and Morita, T. 1995. Photocontrol of parasitic flowering Cuscuta japonica Chois cultured in vitro. Plant Cell Physiol. 36: 533-536.

Furuhashi, K., Tada, Y., Okamoto, K., Sugai, M., Kubota, M. and Watanabe, M. 1997. Phytochrome participation in induction of haustoria in Cuscuta japonica, a holoparasitic flowering plant. Plant Cell Physiol. 38: 935-940.

Gaertner, E. E. 1950. Studies of seed germination, seed identification, and host relationships in Dodders, Cuscuta spp. Mem. Cornell Agric. Exp. Sta. 294: 1-56.

Gao, Z. Y. and Gan, J. 1992. Biological control of dodder - a review on research progress of the bioherbicide "Lu Bao No. 1". Chinese J. Biol. Control 8: 173-175.

Gao, Z. Y. and Gan, J. 2003. Biological control of dodder - a review on research progress of the bioherbicide "Lu Bao No. 1". Monthly Bulletin - Department of Agriculture, Fisheries \& Parks, Bermuda 64: 173-175.

Gandhi, K. N., Thomas, R. D. and Hatch, S. L. 1987. Cuscutaceae of Louisiana. Sida 12: 361-379.

Gilmore, M. R. 1914 (reprinted 1977). Uses of plants by the Indians of the Missouri River Region. University of Nebraska Press, Lincoln, NB. 125 pp.

Goldwasser, Y., Lanini, W. T. and Wrobel, R. L. 2001. Tolerance of tomato varieties to lespedeza dodder. Weed Sci. 49: 520-523.

Gómez, J. M. 1994. Importance of direct and indirect effects in the interaction between a parasitic angiosperm (Cuscuta epithymum) and its host (Hormatophylla spinosa). Oikos 71: 97-106.

Greene, H. C. 1953. Notes on Wisconsin parasitic fungi. XIX. Am. Midl. Nat. 50: 501-508. 
Greene, H. C. 1964. Notes on Wisconsin parasitic fungi. XXXI. Trans. Wisconsin Acad. Sci. 53: 197-215.

Gronovius, J. F. 1762. Flora Virginica: Exhibens plantas, Quas Johannes Claytonus in Virginia crescentes observavit, collegit \& obtulit J. F. Gronovio, cujus studio \& opera descriptae \& in ordinem sexualem systematicum redactae sistuntur, Lugduni Batavorum, $176 \mathrm{pp}$.

Grubert, M. 1974. Studies on the distribution of myxospermy among seeds and fruits of Angiospermae and its ecological importance. Acta Biol. Venez. 8: 315-551.

Gruzdev, G. and Prishchepo, N. 1984. Seed viability of Cuscuta campestris under natural and laboratory conditions. Izvestiia Timiriazevskaia Sel'skokhoziaistvennaia Akad. 4: 174-176.

Guo, F.-G. and Li, Y.-H. 2000. Effect of spore germination and pathogenicity of parasitic fungi on dodders by solvent and temperature. Chin. J. Biol. Control 16: 81-83.

Guo, F.-G., Li, Y.-H. and Deng, F.-Z. 1998. Screening biological control fungi for dodders on woody hosts. Chin. J. Biol. Control 14: $159-162$.

Habib, S. A. and Rahman, A. A. A. 1988. Evaluation of some weed extracts against field dodder on alfalfa (Medicago sativa). J. Chem. Ecol. 14: 443-452.

Haccius, B. and Troll, W. 1961. Über die sogennante Wurtzelhaare an den Keimpflanzen von Drosera-und Cuscuta arten. Beitr. Biol. Pflanzen 36: 139-157.

Haidar M. A. 2003. Characterization of the interaction between cryptochromes and phytochromes in blue light-induced coiling and prehaustoria development of dodder (Cuscuta campestris) seedlings Ann. Appl. Biol. 143: 57-62.

Haidar, M. A., Orr, G. L. and Westra, P. 1997. Effects of light and mechanical stimulation on coiling and prehaustoria formation in Cuscuta spp. Weed Res. 37: 219-228.

Haidar, M. A., Orr, G. L. and Westra, P. 1998. The response of dodder (Cuscuta spp.) seedlings to phytohormones under various light regimes. Ann. Appl. Biol. 132: 331-338.

Haidar, M. A., Nath, R. P. and Thakur, S. K. 1999a. Use of plant extracts as bio-control agents of nematodes. J. Res. Birsa Agric. Univ. 11: 241-242.

Haidar, M. A., Iskandarani, N., Sidahmed, M. and Baalbaki, R. 1999b. Response of field dodder (Cuscuta campestris) seeds to soil solarization and chicken manure. Crop Prot. 18: 253-258.

Haupt, S. and Neumann, S. 1996. Transfer of assimilates and xenobiotics from host plants to the parasite Cuscuta reflexa Roxb. Pages 355-364 in M. T. Moreno, J. I. Cubero, D. Berner, D. Joel, L. J. Musselman, and C. Parker, eds. Advances in parasitic plant research. Junta de Andalucia, Dirección General de Investigación Agraria, Cordoba, Spain.

Haupt, S., Oparka, K. J., Sauer, N. and Neumann, S. 2001. Macromolecular trafficking between Nicotiana tabacum and the holoparasite Cuscuta reflexa. J. Exp. Bot. 52: 173-177.

Heap, I. 2002. International survey of herbicide resistant weeds. [Online] Available: www.weedscience.com [2004 March].

Heintz, W. 1989. Transmission of a new mycoplasma-like organism (MLO) from Cuscuta odorata Ruiz \& Pav. to herbaceous plants and attempts to its elimination in the vector. J. Phytopathol. 125: $171-186$.

Hibberd, J. M., Bungard, R. A., Press, M. C., Jeschke, W. D., Scholes, J. D. and Quick, W. P. 1998. Localization of photosynthetic metabolism in the parasitic angiosperm Cuscuta reflexa. Planta 205: 506-513.

Hibberd, J. M. and Jeschke, W. D. 2001. Solute flux into parasitic plants. J. Exp. Bot. 52: 2043-2049.

Holm, L., Doll, J., Holm, E., Pancho, J. and Herberger, J. 1997. World weeds: Natural histories and distribution. John Wiley \& Sons Inc., Toronto, ON. 1129 pp.
Holmgren, P. K., Holmgren, N. H. and Barnett, L. C. 1990. Index herbariorum. Part I: The herbaria of the world. 8th ed. New York Botanical Garden, Bronx, NY. 693 pp.

Hosford, R. M. 1967. Transmission of plant viruses by dodder. Bot. Rev. 33: 387-406.

Hsieh, T. C., Lu, X. H., Guo, J. Q., Xiong, W., Kunicki, J., Darzynkiewicz, Z. and Wu, J. M. 2002. Effects of herbal preparation Equiguard ${ }^{\mathrm{TM}}$ on hormone-responsive and hormone-refractory prostate carcinoma cells: mechanistic studies. Int. J. Oncol. 20: 681-689.

Hui, L. and ShiBin, Y. 2002. A preliminary study of the toxins of Colletotrichum gloeosporioides (Penz) Sacc. f. sp. cuscutae Chang. J. Sichuan Agric. Univ. 20: 246-248.

Hutchinson, J. M. and Ashton, F. M. 1979. Effect of desiccation and scarification on the permeability and structure of the seed coat of Cuscuta campestris. Am. J. Bot. 66: 40-46.

Hutchinson, J. M. and Ashton, F. M. 1980. Germination of field dodder (Cuscuta campestris). Weed Sci. 28: 330-333.

Ihl, B. and Wiese, K. 2000. Studien an Cuscuta reflexa Roxb.: VIII. Mechanische Haustorien-induktion an nichtwindenden Achsen des Parasiten. Flora (Jena) 195: 1-8.

Invaders database system. 2004. Agricultural Research Service U.S.D.A. [Online] Available: http://invader.dbs.umt.edu [2004 February].

Jacob, F. 1966. The release of the flowering process in a short-day plant Cuscuta reflexa. Flora Allgemeine Botanishe Zeitung 156: $558-572$

Jana, S. and Bhattacharjee, A. 1988. Effects of combinations of heavy metal pollutants on Cuscuta reflexa. Water Air Soil Pollut. 42: 303-310.

Jeschke, W. D. und Hilpert, A. 1997. Sink-stimulated photosynthesis and sink-dependent increase in nitrate uptake: nitrogen and carbon relations of the parasitic association Cuscuta reflexaRicinus communis. Plant Cell Environ. 20: 47-56.

Jeschke, W. D., Baumel, P., Rath, N., Czygan, F. C. and Proksch, P. 1994. Modelling the flow and partitioning of carbon and nitrogen in the holoparasite Cuscuta reflexa Roxb and its host Lupinus albus L. II. Flows between host and parasite and within the parasitized host. J. Exp. Bot. 45: 801-812.

JianZhong, H. and YangHan, L. 1993. Development and deterioration of primary root of parasitic plant dodder. J. Nanjing Agric. Univ. 16: 12-17.

Johri, B. M. 1987. Embryology of Cuscuta L. (Cuscutaceae). Pages 445-448 in H. C. Weber and W. Forstreuter, eds. Parasitic flowering plants. Philipps-Universität, Marburg, Germany.

Johri, B. M., Ambegaokar, K. B. and Srivastava, P. S. 1992. Comparative embryology of Angiosperms. Vol. 1, 2. SpringerVerlag, Berlin, Germany. 1221 pp.

Jordá, C., Font, I., Martínez, P., Juarez, M., Ortega, A. and Lacasa, A. 2001. Current status and new natural hosts of Tomato yellow leaf curl virus (TYLCV) in Spain. Plant Dis. 85: 445

Julien, M. H. (ed.) 1992. Biological control of weeds: a world catalogue of agents and their target weeds. CAB International, Wallingford, UK. 118 pp.

Kamiska, M. and Korbin, M. 1999. Graft and dodder transmission of phytoplasma affecting lily to experimental hosts. Acta Physiol. Plant. 21: 21-26.

Kamiska, M., Liwa, H. and Rudziska-Langwald, A. 2001a. The association of phytoplasma with stunting, leaf necrosis and witches' broom symptoms in magnolia plants. J. Phytopathol. 149: 719-724.

Kamiska, M., Korbin, M. and Rudziska-Langwald, A. 2001b. The response of lily seedlings to inoculation with aster yellows phytoplasma by leafhopper and dodder. Phytopathologia Polonica 21: 69-79. 
Kartesz, J. T. 1998. A synonymized checklist of the vascular flora of the United States, Puerto Rico, and the Virgin Islands. Full Text Index. [Online] Available: http://www.csdl.tamu.edu/FLORA/ b98/check98.htm [2004 March]

Kelly, C. K. 1990. Plant foraging: a marginal value model and coiling response in Cuscuta subinclusa. Ecology 7: 1916-1925.

Kelly, C. K. 1992. Resource choice in Cuscuta europaea. Proc. Nat. Acad. Sci. USA. 89: 12194-12197.

Kelly, C. K. 1994. On the economics of plant growth: stolon length and ramet initiation in the parasitic clonal plant Cuscuta europaea. Evol. Ecol. 8: 459-470.

Kelly, C. K. and Horning, K. 1999. Acquisition order and resource value in Cuscuta attenuata. Proc. Nat. Acad. Sci. USA 96: $13219-13222$.

Kelly, C. K., Harris, D. and Perez-Ishiwara, R. 2001. Is breaking up hard to do? Breakage, growth, and survival in the parasitic clonal plant Cuscuta corymbosa (Convolvulaceae). Am. J. Bot. 88: 1458-1468.

Khalid, A. N. and Iqbal, S. H. 1996. Mycotrophy in a vascular stem parasite Cuscuta reflexa. Mycorrhiza 6: 69-71.

Kingsbury, J. M. 1964. Poisonous plants of the United States and Canada. Prentice-Hall, Inc. Englewood Cliffs, 432 pp.

Knepper, D. A., Creager, R. A. and Musselman, L. J. 1990. Identifying dodder seed as contaminants in seed shipments. Seed Sci. Technol. 18: 731-741.

Koch, M. A., Binder, C. and Sanders, R. A. 2004. Does the generalist parasitic plant Cuscuta campestris selectively forage in heterogeneous plant communities? New Phytol. 162: 147-155.

Koskela, T., Puustinen, S., Salonen, V. and Mutikainen, P. 2002. Resistance and tolerance in a host plant-holoparasitic plant interaction: genetic variation and costs. Evolution 56: 899-908.

Kothekar, V. 1970. A handbook of pests, diseases and weeds of quarantine significance. Agric. Res. Serv. US Dept. Agric. Amerind Publishing Co. Ltd., New Delhi, India. pp. 206-224.

Krause, K., Berg, S. and Krupinska, K. 2003. Plastid transcription in the holoparasitic plant genus Cuscuta: parallel loss of the rrn16 PEP-promoter and of the rpoA and rpoB genes coding for the plastid-encoded RNA polymerase. Planta 216: 815-813.

Kroschel, J. 2001. A technical manual for parasitic weed research and extension. Kluwer Academic Publishers, London, UK. 256 pp.

Kuhn, J. 1868. Wie ist dem Umsichgreinfen der Kleeseide am Wirsamsten au begegnen? Zeitschr. des landwirthsch. Central Vereins der Prov. Sachses 25: 237-242.

Kuijt, J. 1969. The biology of parasitic flowering plants. Univ. of Calif. Press, Berkeley, CA. 246 pp.

Kuijt, J. and Toth, R. 1976. Ultrastructure of angiosperm haustoria: a review. Ann. Bot. 40: 1121-1130.

Kujawski, R. F. and Truscott, F. H. 1974. Photocontrol of hook opening in Cuscuta gronovii. Plant Physiol. 53: 610-614.

Kumar, J. and Mohan, J. 1994. Transmission of lentil mosaic virus. Legume Res. 17: 217-221.

Kuoh, C. S. and Liao, G. I. 1993. Flower initiation and development in Cuscuta australis R. Br. (Convolvulaceae). Taiwania 38: 99-107.

Lados, M. 1999. Effect of temperature, $\mathrm{pH}$ and host plant extract on the germination of Cuscuta trifolii and C. campestris seeds. Növénytermeles 48: 367-376 [in Hungarian, English abstract].

Lampe, K. F. and McCann, M. A. 1985. AMA handbook of poisonous and injurious plants. American Medical Association, Chicago, IL. 432 pp.

Lane, H. C. and Kasperbauer, M. J. 1965. Photomorphogenetic responses of dodder seedlings. Plant Physiol. 40: 109-116.

Lane, H. C., Baker, J. E. and Danielson, L. L. 1965. Effect of diuron on photosynthesis of dodder seedlings. Weeds 13: 371-372.
Lea, J. A. and Stewart, G. R. 1978. Ecological aspects of nitrogen assimilation. Pages 1-43 in H. W. Woolhouse, ed. Advances in botanical research. Vol. 4. Academic Press, New York, NY. Leach, C. M. 1958. A disease of dodder caused the fungus Colletotrichum destructivum. Plant Dis. Rep. 42: 827-829.

Leck, M. A. and Simpson, R. L. 1995. Ten-year seed bank and vegetation dynamics of a tidal freshwater marsh. Am. J. Bot. 82: $1547-1557$.

Lee, K. B. and Lee, C. D. 1989. The structure and development of the haustorium of Cuscuta australis. Can. J. Bot. 67: 2975-2982.

Loi, N., Carraro, L., Musetti, R., Pertot, I. and Osler, R. 1995. Dodder transmission of two different MLOs from plum trees affected by "leptonecrosis". Acta Hortic. 386: 465-470.

Loo, S. W. 1946. Cultivation of excised stem tips of dodder in vitro. Am. J. Bot. 33: 295-300.

Lyshede, B. O. 1984. Seed structure and germination in Cuscuta pedicellata with some notes on Cuscuta campestris. Nord. J. Bot. 4: 669-664.

Lyshede, B. O. 1985. Morphological and anatomical features of Cuscuta pedicellata and C. campestris. Nord. J. Bot. 5: 65-77.

Lyshede, B. O. 1992. Studies of mature seeds of Cuscuta pedicellata and C. campestris by electron microscopy. Ann. Bot. 69: 365-371. MacLeod, D. G. 1961a. Photosynthesis of Cuscuta. Experientia 17: 542-547.

MacLeod, D. G. 1961b. Some anatomical and physiological observations on two species of Cuscuta. Trans. Bot. Soc. Edin. 39: 302-315.

MacLeod, D. G. 1963. The parasitism in Cuscuta. New Phytol. 62: 257-263.

Machado, M. A. and Zetsche, K. A. 1990. A structural, functional and molecular analysis of plastids of the holoparasites Cuscuta reflexa and Cuscuta europaea. Planta 181: 91-96.

Maixner, M., Ahrens, U. and Seemüller, E. 1994. Detection of mycoplasmalike organisms associated with a yellows disease of grapevine in Germany. J. Phytopathol. 142: 1-10.

Malik, C. P. and Singh, M. B. 1980. Physiological and biochemical aspect of parasitism. Ann. Rev. Plant Sci. 1: 67-113.

Marcone, C., Serio, F. di and Ragozzino, A. 1995. Peach rosette: a disease associated with mycoplasma-like organisms. Acta Hortic. 386: 471-479.

Marcone, C., Ragozzino, A. and Seemüller, E. 1997. Dodder transmission of alder yellows phytoplasma to the experimental host Catharanthus roseus (periwinkle). Eur. J. Forest Pathol. 27: 347-350.

Marcone, C., Hergenhahn, F., Ragozzino, A. and Seemüller, E. 1999. Dodder transmission of pear decline, European stone fruit yellows, rubus stunt, picris echoides yellows and cotton phyllody phytoplasmas to periwrinkle. J. Phytopathol. 147: 187-192.

McNeal, J. R. and DePamphilis, C. W. 2000. Origin and molecular systematics of the parasitic plant genus Cuscuta (dodder). Botanical Society of America Abstract. [Online] Available: http://www.botany2000.org/section13/abstracts/227.shtml [2004 March].

Menke, H. F. 1954. Dodder infestation can halt certified seed production. Western Feed and Seed 9: 36-37.

Metcalfe, C. R. and Chalk, L. 1957. Anatomy of the Dicotyledons; leaves, stem, and wood in relation to taxonomy, with notes on economic uses. Clarendon Press, Oxford, UK. 1500 pp.

Moerman, E. D. 1977. American medical ethnobotany: a reference dictionary. Garland Publishing, New York and London. 527 pp.

Mojumder, V. and Goswami, B. K. 1987. Effect of aqueous extracts of madar (Calotropis gigantea) and amarbel (Cuscuta reflexa) on larval mortality, hatching from egg-masses and subsequent penetration into tomato roots. Ann. Agric. Res. 8: 285-289. 
Mohammad, R., Nasir, M. A. and Bhatti, M. A. R. 1984. Antifungal properties of certain common wild plants against different fungi. Pakistan J. Agric. Res. 5: 236-238.

Movsesyan, T. B. and Azaryan, Kh. A. 1974. Poisoning produced by feeding dodder (Cuscuta campestris) to animals. Veterinariya (Moscow) 6: 92 [in Russian, English abstract].

Mulligan, G. A. and Munro, D. B. 1990. Poisonous plants of Canada. Biosystematics Research Centre, Research Branch Agriculture Canada, Ottawa, ON. Publ. 1842/E. 96 pp.

Musselman, L. J. 1986. The genus Cuscuta in Virginia. Castanea 51: 188-196.

Nadler-Hassar, T. and Rubin, B. 2003. Natural tolerance of Cuscuta campestris to herbicide inhibiting amino acid biosynthesis. Weed Res. 43: 341-347.

Nir, E., Rubin, B. and Zharasox, S. W. 1996. On the biology and selective control of field dodder (Cuscuta campestris). Pages 809-816 in M. T. Moreno, J. I. Cubero, D. Joel, L. J. Musselman, and C. Parker, eds. Advances in parasitic weed symposium, Cordoba, Spain.

Nisa, M., Akbar, S. and Tariq M. 1985. Anti-inflammatory activity of Cuscuta chinensis. Fitoterapia. 56: 315-317.

Nisa, M., Akbar, S., Tariq M. and Hussain, Z. 1986. Effect of Cuscuta chinensis water extract on 7,12-dimethylbenz[a] anthracene-induced skin papillomas and carcinomas in mice. J. Ethnopharmacol. 18: 21-31.

Nojavan, M. and Montakhab, M. H. 2001. The effect of herbicide treatments on dodder seed germination and the possibility of its chemical control in vineyards. Agric. Sci. Technol. 15: 13-21. O'Brien C. W. and Anderson, D. M. 1996. A catalog of the Coleoptera of America north of Mexico. Family Curculionidae: subfamily Erirhininae. USDA, Agriculture Handbook 529-143f, 39 pp. Oganyan, E. A. 1976. The most susceptible growth stages of dodder to the action of trichothecin. Biologicheskii Zhurnal Armenii 29: 92-94.

Orr, G. L., Haidar, M. A. and Orr, D. A. 1996a. Smallseed dodder (Cuscuta planiflora) phototropism toward far-red when in white light. Weed Sci. 44: 233-240.

Orr, G. L., Haidar, M. A. and Orr, D. A. 1996b. Smallseed dodder (Cuscuta planiflora) gravitropism in red light and red plus farred. Weed Sci. 44: 795-796.

Panda, M. M. and Choudhury, N. K. 1992. Effect of irradiance and nutrients on chlorophyll and carotenoid content and Hill reaction activity in Cuscuta reflexa. Photosynthetica 26: 585-592.

Parker, C. and Riches, C. R. 1993. Parasitic weeds of the world. Biology and control. CAB International, Wallingford, UK. 332 pp. Pazy, B. and Plitmann, U. 1995. Chromosome divergence in the genus Cuscuta and its systematic implications. Caryologia 48: 173-180.

Perkins, K. and Payne W. 1978. Guide to the poisonous and irritant plants of Florida. University of Florida, Circular 441, Gainesville, FL. Pierce, W. D. 1939. The dodder and its insects. Bull. S. Calif. Acad. Sci. 38: 43-53.

Pozzer, L., Dusi, A. N., Lima, M. I. and Kitajima, E. W. 1995. Caracterização de um isolado brasileiro do "sweet potato feathery mottle virus" infectando batata-doce. Fitopatologia Brasileira 20: 65-71.

Prather, L. A. and Tyrl, J. 1993. The biology of Cuscuta attenuata Waterfall. Proc. Okla. Acad. Sci. 73: 7-13.

Prenner, G., Deutsch, G. and Harvey, P. 2002. Floral development and morphology in Cuscuta reflexa Roxb. (Convolvulaceae) Stapfia 80: 311-322.

Pundir, Y. P. S. 1985. Preliminary observations on the control of Lantana camara L. by Cuscuta santapaui Benerji \& Das in Dehradun Valley. Acta Bot. Indica 13: 298-300.
Qin, D.-N., She, B.-R., She, Y.-C. and Wang, J.-H. 2000. Effects of flavonoids from semen Cuscutae on the reproductive system in male rats. Asian J. Androl. 2: 99-102.

Rajagopal, I., Ramasubramanian, T. S., Paliyath, G. and Mahadevan, S. 1988. Hormones and Cuscuta development: Interaction of cytokinin and indole-3-acetic acid in the growth and curvature of subapical stem segments. J. Plant Growth Regul. 7: 121-132.

Ramasubramanian, T. S., Paliyath, G., Rajagopal, I., Maheshwari, R. and Mahadevan, S. 1988. Hormones and Cuscuta development: in vitro induction of haustoria by cytokinins and its inhibition by other hormones. J. Plant Growth Regul. 7: 133-144.

Rath, G. C. and Mohanty, S. S. 1987. Production of haustoria of Cuscuta chinensis in contact with glass surface. Indian Phytopatol. 40: 415-416.

Rath, G. C. and Mohanty, S. S. 1988. Observations of some grass hosts of Cuscuta chinensis. Plant Pathol. Newsletter 6: 35-36.

Robinson, R. D., Williams, L. A. D., Lindo, J. F., Terry, S. I. and Mansingh, A. 1990. Inactivation of Strongyloides stercoralis filariform larvae in vitro by six Jamaican plant extracts and three commercial anthelmintics. West Indian Med. J. 39: 213-217.

Roemer, J. J. and Schultes, J. A. 1820. Systema Vegetabilium. Vol. 4. Stuttgart, Germany. 321 pp.

Roos, U.-P. and Aldrich, H. C. 1988. Intracellular localization and morphology of rhabdovirus-like particles in dodder (Cuscuta sp.). Can. J. Bot. 66: 2499-2504.

Rothe, K., Diettrich, B., Rahfeld, B. and Luckner, M. 1999. Uptake of phloem-specific cardenolides by Cuscuta sp. growing on Digitalis lanata and Digitalis purpurea. Phytochemistry 51 : 357-361.

Rubin, B. 1995. Herbicide resistance outside north America and Europe: Causes and significance. Proc. Int. Symp. on Weed and Crop Resistance to Herbicides. Cordoba, Spain. 1995 April.

Sahm, A., Czygan, F. C. and Proksch, P. 1994. Resistance of tomato (Lycopersicon esculentum) to dodder (Cuscuta reflexa). Acta Hortic. 381: 650-653.

Sahm, A., Pfanz, H., Grünsfelder, M., Czygan, F. C. and Proksch, P. 1995. Anatomy and phenylpropanoid metabolism in the incompatible interaction of Lycopersicon esculentum and Cuscuta reflexa. Bot. Acta 108: 358-364.

Sahu, D. and Choudhury, N. K. 2000. Photosynthesis in Cuscuta reflexa, an angiospermic holoparasite. Adv. Plant Sci. 13: 153-158.

Sanders, I. R., Koide, R. T. and Shumway, D. L. 1993. Mycorrhizal stimulation of plant parasitism. Can. J. Bot. 71: 1143-1146.

Sandler, H. A., Else, M. J. and Sutherland, M. 1997. Application of sand for inhibition of swamp dodder (Cuscuta gronovii ) seedling emergence and survival on cranberry (Vaccinium macrocarpon) Weed Technol. 11: 318-323.

Sandler, H. A. and Mason, J. 2004. Efficacy of floodind for the control of dodder (Cuscuta gronovii) and several broad-leaved species in commercial cranberry production in Southeastern Massachusetts - A 2-year study. Proc. North Centr. Weed Sci. Soc. 58: 263 (Abst.).

Schmelzer, K. 1958. Beiträge zur Kenntnis der Übertragbarkeit von Viren durch Cuscuta- Arten. J. Phytopathol. 28: 1-56.

Scoggan, H. J. 1979. The flora of Canada. Part. 4 Dicotyledoneae (Loasaceae to Compositae). National Museum of Natural Sciences Publications in Botany, Ottawa, ON. 4: 1254-1256.

Scott, S. W. and Zimmerman, M. T. 2001. Peach rosette, little peach, and red suture are diseases induced by a phytoplasma closely related to western X-disease. Acta Hortic. 550: 351-354. 
Shaw, C. G. 1973. Host fungus index for the Pacific Northwest I. Hosts. Washington State Univ. Agric. Exp. Sta. Bull. 765: 1-121. Sherman, T. D., Pettigrew, W. T. and Vaughn, K. C. 1999. Structural and immunological characterization of the Cuscuta pentagona L. chloroplast. Plant Cell Physiol. 40: 592-603.

Sherman, T. D. and Vaughn, K. C. 2003. Root cells of the parasitic weed dodder (Cuscuta pentagona) show signs of programmed cell death. American Society of Plant Biologists. Abstract 262. [Online] Available: http://abstracts.aspb.org/aspp2000/public/ P28/0693.html [2004 February].

Sherman, T. D., Barger, T. W., Hoffman, J. C. and Vaughn, K. C. 2003. Abnormal dodder (Cuscuta pentagona) root morphology is due to unusual cytoskeletal and wall composition. American Society of Plant Biologists. Abstract 388. [Online] Available: http://abstracts.aspb.org/pb2002/public/P51/0343.html [2004 February].

Shimi, P., Bayat Asadi, H., Rezapanah, M. R. and Koliaii, R. 1995. A study of Smicronyx robustus Faust (Curculionidae) as a biological control agent of eastern dodder (Cuscuta monogyna Vahl.) in Iran. J. Agric. Sci. Islamic Azad Univ. 1: 43-51.

Simmons, E. G. 1998. Alternaria themes and variations. Mycotaxon 68: 417-427.

Singh, M., Tewari, K. K. and Krishnan, P. S. 1963. Metabolism of angiosperm parasites: Part. I. Phosphate partitioning in Cuscuta reflexa Roxb. and infested plants. Indian J. Exp. Biol. 1: 207-209. Singh, M., Singh, D. V., Mishra, P. C., Tewari, K. K. and Krishnan, P. S. 1968. Biochemical aspects of parasitism by angiosperm parasites: starch accumulation. Physiol. Plant. 21: 525-538.

Singh, A and Singh, M. 1997. Incompatibility of Cuscuta haustoria with the resistant hosts - Ipomoea batatas L. and Lycopersicon esculentum Mill. J. Plant Physiol. 150: 592-596.

Sitkin, R. S. 1976. Parasite-host interactions of field dodder (Cuscuta campestris). MSc Thesis, Cornell University, Ithaca, NY. $64 \mathrm{pp}$.

Spisar, K. 1910. Beiträge zur Physiologie der Cuscuta gronovii. Ber. Dtsch. Bot. Ges. 28: 329-334.

Srivastava, A. K., Jr. 2002. Abortifacient plants of Gorakhpur. J. Living World. 9: 22-24.

Srivastava, H. S. and Chauhan, J. S. 1977. Seed germination, seedling growth and nitrogen and pigment concentration in dodder as effected by inorganic nitrogen. Z. Pflanzenphysiol. 84: 391-398.

Srivastava, S. and Dwivedi, U. N. 2003. Modulation of key nitrogen assimilating enzymes by NAA and in vitro culture in Cuscuta reflexa. Plant Physiol. Biochem. 41: 65-71.

Stefanovic, S. and Olmstead, R. G. 2004. Testing the phylogenetic position of a parasitic plant (Cuscuta, Convolvulaceae, Asteridae): Bayesian inference and the parametric bootstrap on data drawn from three genomes. Syst. Biol. 53: 384-399.

Stefanovic, S., Krueger, L. and Olmstead, R. G. 2002. Monophyly of the Convolvulaceae and circumscription of their major lineages based on DNA sequences of multiple chloroplast loci. Am. J. Bot. 89: 1510-1522.

Stephens, H. A. 1980. Poisonous plants of the Central United States. The Regents Press of Kansas, Lawrence, KS. 165 pp.

Stevens, O. A. 1932. The number and weight of seeds produced by the weeds. Am. J. Bot. 19: 784-794.

Stojanovic, D. and Mijatovic, K. 1973. Distribution, biology and control of Cuscuta spp. in Yugoslavia. Proc. EWRC Symp. on Parasitic Weeds, Malta. pp. 269-279.

Stojsin, V., Maric, A. and Jocic, B. 1991. Harmfulness of Cuscuta campestris Yuncker on sugarbeet under varying mineral nutrition. Zastita Bilja 42: 357-363.
Strasser, E. G. 1988. Studies on the use of dry heat to decontaminate niger seed (Guizotia abyssinica) infested with dodder seed (Cuscuta spp.). Seed Sci. Technol. 16: 501-505.

Subandiyah, S. 1994. Transmission of citrus vein phloem degeneration (CVPD) to periwinkle through dodder. Agrivita 17: 21-22. Subramaniam, K. and Mahadevan, S. 1994. The cDNA sequence of cytochrome b5 associated with cytokinin-induced haustoria formation in Cuscuta reflexa. Gene 149: 375-376.

Subramaniam, K., Ranie, J., Srinivasa, B. R., Sinha, A. M. and Mahadevan, S. 1994. Cloning and sequencing of a cDNA encoding a novel hybrid proline-rich protein associated with cytokinininduced haustoria formation in Cuscuta reflexa. Gene 141: 297-210.

Tada, Y., Sugai, M. and Furuhashi, K. 1996. Haustoria of Cuscuta japonica, a holoparasitic flowering plant, are induced by the cooperative effects of far-red light and tactile stimuli. Plant Cell Physiol. 37: 1049-1053.

Tada, I., Wakasugi, T., Nishikawa, A., Furuhashi, K. and Yamada, K. 2000. Developmental regulation of a gene coding for a low-molecular-weight heat shock protein during haustorium formation in the seedlings of a holoparasitic plant, Cuscuta japonica. Plant Cell Physiol. 41: 1373-1380.

Takhtajan, A. 1997. Diversity and classification of flowering plants. Columbia University Press, New York, NY. 743 pp.

Tiagi, B. 1951. A contribution to the morphology and embryology of Cuscuta hyalina Roth. and $C$. planifora Tenore. Phytomorphology 1: 9-21.

Tiagi, B. 1966. Floral morphology of Cuscuta reflexa Roxb. and C. lupuliformis Krocker with a brief review of the literature on the genus Cuscuta. Bot. Mag. Tokyo 79: 89-97.

Tingey, D. C. and Allred, K. R. 1961. Breaking dormancy in seeds of Cuscuta approximata. Weeds 9: 429-436.

Trevawas, A. 2003. Aspects of plant intelligence. Ann. Bot. 92: 1-20. Truscott, F. H. 1958. On the regeneration of new shoots from isolated dodder haustoria. Am. J. Bot. 45: 169-177.

Truscott, F. H. 1966. Some aspects of morphogenesis in Cuscuta gronovii. Am. J. Bot. 53: 739-750.

Tsivion, Y. 1978. Possible role of cytokinins in non-specific recognition of a host and in early growth of haustoria in the parasitic plant Cuscuta campestris. Bot. Gaz. 139: 27-31.

Tsivion, Y. 1979. Resistance reaction of tomato and bean plants to infections by Cuscuta. Phytoparasitica 7: 141.

Valencia, M., Arroyave, J. A., Laberry, R. and Lozano, C. 1993. Estudio sobre transmisión del agente causal del superbrotamiento de la yuca (Manihot esculenta Cranz.). Fitopatol. Colomb. 17: 39-45

van der Kooij, T. A. W., Krause, K., Dörr, I. and Krupinska, K. 2000. Molecular, functional and ultrastructural characterization of plastids from six species of the parasitic flowering plant genus Cuscuta. Planta. 210: 701-707.

van der Valk, A. G. and Davis, C. B. 1976. The seed banks of prairie glacial marshes. Can. J. Bot. 54: 1832-1838.

von Denffer, D. 1948. Über die Bedeutung des Blühtermins der Wirspflanzen von Cuscuta gronovii Willd. für die Blütenbildung des Schmaretzers. Biol. Zentralbl. 67: 175-189.

Vaughn, K. C. 2002. Attachment of the parasitic weed dodder to the host. Protoplasma 219: 227-237.

Vaughn, K. C. 2003. Dodder hyphae invade the host: a structural and immunocytochemical characterization. Protoplasma 220: 189-200.

Verdcourt, B. 1948. Biological flora of the British Isles. Cuscuta L. J. Ecol. 36: 356-365.

Volkov, O. G. 1989. Prospects for biological regulation of Cuscuta. Zashchita Rasteni (Moskva) 11: 18-19. 
Wan, F. H. and Wang, R. 1991. Achievements of biological weed control in the world and its prospect in China. Chinese J. Biol. Control 7: 81-87.

Ward, D. E. 1984. Chromosome counts from New Mexico and Mexico. Phytologia 56: 55-60.

Watson, A. K., Gressel, J., Sharon, A. and Dinoor, A. 2000. Colletotrichum strains for weed control. Pages 245-265 in D. Prusky, S. Freeman, and M. B. Dickman, eds. Colletotrichum: host specificity, pathology and host-pathogen interaction. APS Press, The American Phytopatological Society, St. Paul, MN.

Weinberg, T., Lalazar, A. and Rubin, B. 2003. Effects of bleaching herbicides on field dodder (Cuscuta campestris). Weed Sci. 51: 663-670.

Welliver, R. A. and Halbrendt, J. M. 1992. Dodder transmission of tomato ringspot virus. Plant Dis. 76: 642.

Werner, M., Uehlein, N., Proksch, P. and Kaldenhoff, R. 2001. Characterization of two tomato aquaporins and expression during the incompatible interaction of tomato with the plant parasite Cuscuta reflexa. Planta 213: 550-555.

Wolswinkel, P. 1974. Complete inhibition of setting and growth of fruits of Vicia faba L. resulting from the draining of the phloem system by Cuscuta species. Acta Bot. Neerl. 23: 48-60.

Wolswinkel, P. and Ammerlaan, H. F. 1983. Sucrose and hexose release by excised stem segments of Vicia faba. The sucrose-specific stimulating influence of Cuscuta on sugar release and the activity of acid invertase. J. Exp. Bot. 34: 1516-1527.
Wolswinkel, P., Ammerlaan, A. and Peters, H. F. C. 1984. Phloem unloading of amino acids at the site of attachment of Cuscuta europaea. Physiol. Plant. 75: 13-20.

Xu, M., Dick, I. M., Day, R., Randall, D. and Prince, R. L. 2003. Effects of a herbal extract on the bone density, strength and markers of bone turnover of mature ovariectomized rats. Am. J. Chin. Med. 31: 87-101.

Yuncker, T. G. 1921. Revision of the North American and West Indian species of Cuscuta. Illinois Biol. Monogr. 6: 91-231.

Yuncker, T. G. 1932. The genus Cuscuta. Mem. Torrey Bot. Club. 18: 113-331.

Yuncker, T. G. 1965. Cuscuta. N. Am. Fl. ser. 2, 4: 1-51.

Zhang, T. Y. 1985. A forma specialis of Colletotrichum gloeosporioides on Cuscuta spp. Acta Mycologica Sinica 4: 234-239.

Zimmerman, C. E. 1962. Autotrophic development of dodder (Cuscuta pentagona Engelm.) in vitro. Crop Sci. 2: 449-450.

Zitter, A. T. 2002. A checklist of major weeds and crops as natural hosts for plant viruses in the Northeast. Department of Plant Pathology, Cornell University, Ithaca, NY. [Online] Available: http://vegetablemdonline.ppath.cornell.edu/Tables/WeedHostTabl e.html\#Keys [2004 March]. 